\title{
DIGNIDADE HUMANA E DIREITO ADMINISTRATIVO NO STF: UMA BREVE ANÁLISE CRÍTICA ${ }^{1}$
}

HUMAN DIGNITY AND ADMINISTRATIVE LAW IN THE BRAZILIAN SUPREME COURT: A SHORT CRITICAL ANALYSIS

DIGNIDAD HUMANA Y DERECHO ADMINISTRATIVO EN EL STF: UN BREVE ANÁLISIS CRÍTICO

"Agradava-me enfim que estas mesmas palavras Humanidade, Liberdade e Felicidade não tivessem sido ainda desvalorizadas pelo excesso de aplicações ridículas". - Marguerite Yourcenar, Memórias de Adriano.

\section{José Guilherme Giacomuzzi}

1 Uma versão preliminar deste trabalho foi apresentada em junho de 2014 no III Seminário de Filosofia do Direito e Filosofia Política ocorrido organizado pela Faculdade de Filosofia da Universidade Federal do Rio Grande do Sul, sob a coordenação dos Professores Alfredo C. Storck (Filosofia, UFRGS) e Wladimir B. Lisbôa (Direito, UFRGS), a quem agradeço o convite para participar. Nesta publicação fiz alterações em relação à apresentação feita na ocasião. Ana Paula Ávila leu a primeira versão do texto, e eu lhe agradeço as observações feitas. No seminário, Andrés Rosler e Ronaldo Porto Macedo Júnior fizeram comentários críticos que me ajudaram a deixar o texto menos imperfeito e quiçá com algum sentido. Os avaliadores anônimos da revista Novos Estudos Jurídicos também fizeram críticas construtivas que me provocaram a melhorar o escrito, pelo que Ihes sou grato. Agradeço, por fim, a Manuela Keunecke Leo, que auxiliou na pesquisa da jurisprudência.

2 Doutor em Direito (George Washington University Law School, EUA, 2007), Mestre em Direito (UFRGS, 2000). Professor Adjunto de Direito Administrativo na Faculdade de Direito da UFRGS e Professor no curso de Direito (graduação e mestrado em Direitos Humanos) do UniRitter, campus Porto Alegre, RS. Promotor de Justiça no RS desde 1995. E-mail: jose. giacomuzzi@ufrgs.br 
Resumo: O artigo analisa os acórdãos do Supremo Tribunal Federal brasileiro os quais, após 1988, expressamente invocaram a "dignidade humana" em assuntos ligados ao direito administrativo. Para tanto, o artigo inicia expondo duas das posições críticas mais contundentes sobre a dignidade humana, nomeadamente, a do filósofo Michael Rosen e a do teórico do direito Christopher Möllers, as quais formam o pano de fundo contra o qual as decisões são comparadas. Uma proposta teórica alternativa, de tratamento da dignidade como status, é sugerida. A análise das decisões mostra que o STF faz uso da dignidade humana de forma essencialmente retórica e ornamental. $\mathrm{O}$ artigo conclui que, se quisermos dar sentido e dignidade ao conceito de dignidade humana, o correto seria abandonar a forma atual pela qual o STF vem invocando o mesmo conceito.

Palavras-chave: Dignidade Humana. Direito Administrativo. Supremo Tribunal Federal brasileiro. Análise crítica.

Abstract: This article briefly examines the concept of citizenship, and its historical evolution. It observes that nowadays, it is necessary to include, in this concept (and in the actions of citizens), the primordial role of preserving the environment. It then discusses the anthropomorphic relationship between man and nature. To conclude, it discusses the social function of property, which consists of an activity that is exercised not only in the interest of its owners, but in the interest of society as a whole.

Keywords: Citizenship. Environment. Social and Environmental Responsibility.

Resumen: El presente estudio examina brevemente el concepto de ciudadanía y su evolución histórica. Verifica que, en el momento actual, es necesario incorporar a este concepto (y a la acción del ciudadano) el papel primordial de preservación del medio ambiente. A continuación, discute la relación antropomórfica del hombre en relación a la naturaleza y, por último, aborda la función socioambiental de la propiedad, que consiste en una actividad ejercida no solo en interés de su propietario, sino principalmente en interés de la sociedad.

Palabras clave: Ciudadanía. Medio Ambiente. Responsabilidad Socioambiental. 


\section{INTRODUÇÃO}

omeço com dois fatos incontestáveis. O primeiro: a partir de
meados do século XX, a "dignidade humana" passou ao centro
da cena filosófica, política e jurídica mundial. Como diz o título de um trabalho publicado originalmente em inglês pelo hoje ministro do Supremo Tribunal Federal Luís Roberto Barroso, a dignidade humana está "aqui, lá, em todos os lugares". ${ }^{3}$ Das Declarações e Pactos Internacionais às Constituições dos mais diversos países, com a Lei Fundamental Alemã à frente, a dignidade humana está presente.

A Constituição Brasileira de 1988 não foge à regra e refere-se expressamente à dignidade humana em cinco oportunidades: a primeira está já no Título I (Dos Princípios Fundamentais), como "fundamento da República" (art. 1º III); a segunda, sob a linguagem "existência digna", está no Título VII (Da Ordem Econômica e Financeira) Capítulo I (Dos Princípios Gerais Da Atividade Econômica), como "fim" a ser "assegurado" pela Ordem Econômica. As três últimas inserem-se no Título VIII (Da Ordem Social), Capítulo VI (Da Família, da Criança, do Adolescente, do Jovem e do Idoso), da seguinte forma: como "princípio" do planejamento familiar (art. 226, §7); como "direito" da criança, do adolescente e do jovem (art. 227, caput); e como algo a ser obrigatoriamente defendido pela família, pela sociedade e pelo Estado (art. 230, caput).

O segundo fato é este: nunca na história brasileira o STF esteve tanto em evidência. De instituição pouco conhecida do cidadão comum e Poder menos importante da República, o STF, a partir da redemocratização marcada pela Constituição Federal de 1988, passou ao centro da cena jurídico-política

3 BARROSO, Luís Roberto. Here, There, and Everywhere: Human Dignity in Contemporary Law and in the Transnational Discourse. Boston College International \& Comparative Law Review, v. 35, p. 331-393, 2012. Esse artigo foi traduzido ao português e resultou em livro publicado no ano seguinte. Ver BARROSO, Luís Roberto. Dignidade da Pessoa Humana no Direito Constitucional Contemporâneo: A Construção de um Conceito Jurídico à Luz da Jurisprudência Mundial. Belo Horizonte: Fórum, 2013. 
brasileira. Não é exagero dizer que o STF se transmudou de Poder quase invisível a Poder bastante visível, talvez a ponto de, em certos momentos, ofuscar os demais. No presente século, o STF, para a crítica de uns e o gáudio de outros, permitiu a união de pessoas do mesmo sexo, possibilitou o uso de células tronco em pesquisa científica, bem como o abortamento de fetos anencéfalos, para ficarmos em alguns poucos casos nos quais o tema da dignidade humana esteve sempre presente, sem falar nas decisões sobre matéria eleitoral, como fidelidade partidária e "ficha limpa", além de rumorosas decisões em processos criminais envolvendo o alto escalão da política brasileira. E a lista, sabemos, poderia ser bastante mais longa. Essa virada de $180^{\circ}$ graus em notoriedade (agora não falei "importância") do papel do STF na República brasileira certamente foi ajudada pela decisão - que se mostrou desastrosa ao meu ver - de transmissão, ao vivo e pela televisão, dos seus próprios julgamentos. ${ }^{4}$

O presente estudo junta os dois fatos e pretende comentar criticamente algumas decisões do STF tomadas depois de 1988 em que a dignidade humana foi expressamente invocada. Todas as decisões comentadas dizem com o direito administrativo. Esse corte é arbitrário, mas pode ser minimamente justificado: em razão da proeminência dos direitos humanos no discurso jurídico mundial os quais têm, no plano interno, sua correspondência nos direitos fundamentais -, tem havido na doutrina administrativista nacional uma espécie de frenesi sobre o assunto, a ponto de alguns sustentarem hoje que o direito administrativo deve mudar de fundamento, abandonando o "interesse público" para abraçar a ideia dos "direitos fundamentais", os quais se ancorariam na dignidade humana. ${ }^{5}$ Para a arquitetura do direito administrativo, alterar sua estrutura, suas "fundações", não é sem importância.

4 A Lei Federal no 10.461/2002, de 17 de maio de 2002, criou "um canal reservado ao Supremo Tribunal Federal, para a divulgação dos atos do Poder Judiciário e dos serviços essenciais à Justiça". Nada na referida lei, contudo, obriga o STF a transmitir ao vivo suas sessões de julgamento; a decisão de transmiti-las ao vivo é do próprio STF .

5 O autor que mais expressamente defende essa tese é Marçal JUSTEN FILHO, Marçal. Direito Administrativo de Espetáculo. In: ARAGÃO, Alexandre Santos de; MARQUES NETO, Floriano de Azevedo (Coords.). Direito Administrativo e seus Novos Paradigmas. Belo Horizonte: Fórum, 2008, p. 65-85; e JUSTEN FILHO, Marçal. Curso de Direito Administrativo. 10. ed. São Paulo: Revista dos Tribunais, 2014. O autor sustentava até 2004 que o fundamento do direito administrativo era a supremacia do interesse público; a partir de 2005 passou a alterar sua posição para fundar o direito administrativo na proteção dos direitos fundamentais. 
O problema do fundamento de cada ramo do direito ou instituto jurídico é tormentoso, e não seria diferente com o fundamento dos direitos humanos ou dos direitos fundamentais. Seja como for, é um fato que a dignidade humana tem sido majoritariamente apontada pela maioria dos estudiosos como fundamento dos direitos humanos, e é essa também a razão pela qual cresce a importância teórica de tentar compreender o que significa essa dignidade; igualmente importante, agora no plano prático, é tentar compreender o que diz, no âmbito do direito interno, o STF sobre isso (ainda que em casos limitados ao direito administrativo). Dizendo mais claramente: o problema da pesquisa empreendida neste estudo é, à vista dos acórdãos prolatados depois de 1988 que expressamente invocam a "dignidade humana" em matéria de direito administrativo, verificar se o STF possui alguma compreensão sobre o que significa essa dignidade, ou, mesmo que não a tenha, se é possível dar algum sentido normativo racionalmente rastreável e coerente ao uso da dignidade pelo STF.

Procedo da seguinte forma: no item 1, vou expor as críticas ao conceito de dignidade humana feitas por dois autores proeminentes, para depois, no item 2 , analisar criticamente as decisões do STF sobre o tema contra esse pano de fundo, tentando quando possível oferecer uma proposta alternativa de interpretação dos julgados, para fim de plantar um germe para a construção de um sentido coerente à dignidade. Os autores escolhidos para formar o pano de fundo crítico são o filósofo político inglês Michael Rosen e o juspublicista alemão Christopher Möllers. A proposta alternativa tem base na ideia de dignidade como status, sustentada tanto pelo historiador do direito James $Q$. Whitman quanto pelo filósofo político e teórico do direto Jeremy Waldron. Devo justificar, mesmo que brevemente, essa escolhas.

Para além da força analítica dos argumentos de Rosen e Möllers, há dois motivos inter-relacionados na escolha desses autores para formar o pano de fundo contra o qual as decisões serão confrontadas: (i) seus argumentos, combinados, são bastante representativos das principais críticas feitas por filósofos e teóricos do direito hoje à dignidade humana e ao seu uso; (ii) a maioria, se não todas as decisões do STF aqui analisadas, parecem de alguma maneira encaixar-se nessas críticas. Minha hipótese, portanto, é a de que as decisões do STF sobre o tema da 
dignidade humana em matéria de direito administrativo corroboram e reforçam as críticas dos referidos autores.

Whitman e Waldron, por sua vez, são os autores que melhor têm desenvolvido uma ideia consistente e não retórica da dignidade, examinando-a sob o ponto de vista histórico, político e jusfilosófico e dela tentando retirar algum sentido normativo. Entretanto, e ao contrário do que farei com a corrente que forma o que chamei de "pano de fundo crítico", não exporei com vagar esse ponto de vista, que irá sucintamente explicado e será assumido como hipótese razoável de trabalho na empreitada teórica de dar sentido à dignidade. Seguirá uma conclusão crítica.

\section{QUAL DIGNIDADE?}

Em 2013 foi publicada pela British Academy, da Oxford University Press, uma coletânea de 33 de artigos sobre a dignidade humana, somando mais de 740 páginas e organizada pelo Professor Christopher McCrudden, hoje na Universidade de Michigan. ${ }^{6}$ Para honrar seu título, Understanding Dignity, a coletânea buscou representantes das mais diversas correntes filosóficas, políticas e jurídicas de várias nacionalidades; em conjunto, os artigos reúnem, até onde conheço, os mais autorizados pensadores que tratam do tema, predominantemente angloamericanos. As várias correntes jusnaturalistas ou jusmoralistas e juspositivistas estão todas lá, bem como estão desde entusiastas crédulos na dignidade humana até críticos mais ferrenhos. Interessam aqui somente os artigos de Rosen e Möllers.

\section{A CRÍTICA DE MICHAEL ROSEN}

Michael Rosen, hoje Professorno Departamento de Ciência Política da Universidade de Harvard, abre a Parte II da referida coletânea, reservada expressamente às críticas à dignidade. Seu artigo, intitulado Dignity: The Case Against, é uma espécie segundo round do seu primeiro e mais elaborado estudo sobre o tema, o pequeno-grande

$6 \quad$ O autor escreve um longo capítulo introdutório ao livro, dando um panorama geral sobre o debate. Ver McCRUDDEN, Christopher. In Pursuit of Human Dignity: An Introduction to Current Debates. In: McCRUDDEN, Christopher (Editor). Understanding Human Dignity. Oxford: Oxford U. Press, 2013, p. 1-58. 
livro Dignity: Its History and Meaning, publicado em 2012.7 Limito-me aqui ao artigo, que de certa forma deriva bastante do livro referido.

Rosen começa noticiando o que entre os filósofos (analíticos ao menos) parece ser bastante comum: um ânimo contrário à dignidade. O artigo de Rosen apresenta inúmeros argumentos que pretendem sustentar essa contrariedade. Os argumentos vêm postos em formas de imputações (charges), e o que farei aqui não passa de uma exposição descritiva, tão sucinta quanto possível, desses argumentos. ${ }^{8}$

A primeira imputação é a de que a dignidade é uma ilusão, um logro (humbug). O filósofo, que mais fortemente sustentou isso, como sabem os que lidam com o tema, foi Schopenhauer, frequentemente citado pelos críticos da dignidade. No livro Sobre os Fundamentos da Moral, de 1840, Schopenhauer parece acertar o coração do tema ao sugerir que, embora a palavra dignidade venha associada à grandiosidade e ao status elevado do ser humano, ela na verdade não passa de uma decepcionante fachada; quem espera encontrar nela os fundamentos da moral, verá, na verdade, um espaço vazio: a impressionante fachada desvia nossa atenção do vácuo que por trás dela se encontra.

O próprio Rosen refere que, embora seja uma ilusão, talvez se pudesse sustentar que a história do pensamento político ocidental, de Platão a Bacon, vive de ilusões, e inclusive que precisa delas. Até mesmo Nietzsche uma vez sustentou que a "verdade brutal" de que a "escravidão é da essência da cultura" precisava ser escondida por ilusões sentimentais tais como "direitos do homem", "igualdade" e "dignidade do trabalho". Como diz Rosen, "para um mundo sem coração, é melhor parecer ter coração do que ter sua falta de coração totalmente à mostra". ${ }^{9}$ Mas seria mesmo assim?

O autor sustenta que não e retorna ao uso do termo "fachada" para construir seu argumento. Fachada é uma metáfora forte e significativa, mas o termo

7 Ver ROSEN, Michael. Dignity: Its History and Meaning. Cambridge, MA: Harvard U. Press, 2012.

8 Todos os parágrafos que seguem neste subitem (1.1) têm base em ROSEN, Michael. Dignity: The Case Against. In: McCRUDDEN, Christopher (Editor). Understanding Human Dignity. Oxford: Oxford U. Press, 2013, p. 143-154. A bem da verdade, o que faço neste subitem é quase que integralmente parafrasear o autor. Para não trucar a leitura, vou reservar os rodapés para referências das citações literais. Sobre as traduções do alemão, ver nota 10.

9 ROSEN, Dignity: The Case Against. p. 144. 
"fachada" não parece ter entrado no vocabulário comum antes do início do século XX. A entrada se teria dado com o advento do modernismo arquitetônico, em especial com o trabalho do arquiteto Adolf Loss (1870-1933) e seu texto mais polêmico, Ornamento e Crime, de 1908. A força e a revolta do movimento modernista ampliaram-se depois da $2^{a}$ Guerra Mundial, quando atrás das fachadas de concepção clássica e estática, que representava a lisonja da dignidade dos imperadores e seus rituais galantes, se escondia uma sociedade capitalista e dinâmica, na qual a guerra industrializada provocara o morticínio em massa. Assim, diz Rosen, não somente a ideia nietzschiana de filósofos como aristocratas epistêmicos se tornaria uma repelente forma de arrogância, mas também a sustentação cínica de fachadas ilusórias como a da dignidade aumentaria o poder destrutivo das forças escondidas pelas mesmas fachadas.

A segunda imputação de Rosen vem com a seguinte provocação, retirada da opereta Os Gondoleiros, de William Gilbert e Arthur Sullivan: "quando todo mundo é alguém, joão-ninguém é qualquer um" (when everybody's somebody, nobody's anybody). O autor aqui retoma a sugestão de Schopenhauer e explora a expressão, propositadamente utilizada antes (e anteriormente grifada), "grandiosidade e ao status elevado". Se olharmos, diz Rosen, a história da palavra "dignidade", veremos que muitas das palavras hoje traduzidas ao inglês (e ao português, acrescento eu) por dignidade eram associadas com classe social e majestade — real ou divina.

O raciocínio é este: se a dignidade é uma questão de classe social, então estamos falando de uma convenção social, a qual precisa somente ser aceita para ser válida; não é necessário que a dignidade denote alguma coisa. É aqui que entra a segunda objeção: se não há nada na dignidade além de uma convenção social, qual o significado de atribuir a todos os seres humanos, pelo só fato de serem humanos, algo (a dignidade) que originariamente era atribuído somente a alguns? Vem daí a satírica frase de Gilbert e Sullivan citada.

A terceira imputação de Rosen, que ele chama de "núcleo transcendental", decorre de uma tentativa — que será fracassada, diz Rosen —— de responder à segunda imputação com um algo mais que mera convenção, e que esse algo mais estaria ligado à ideia kantiana, segundo a qual a dignidade seria o fundamento 
último da igualdade e dos direitos humanos, o seu "núcleo transcendental".

Ocorre que, para o Kant de Rosen, não há qualquer núcleo transcendental na dignidade, porque a dignidade em Kant é o nome dado a uma espécie de valor. E os valores, em Kant, são de duas classes, como dito na Fundamentação da Metafísica dos Costumes: "No reino dos fins tudo tem ou um preço ou uma dignidade". Quando algo não tem preço, é porque tem dignidade, diz Kant. Mas, continua Kant, "a moralidade, e a humanidade enquanto capaz de moralidade, são as únicas coisas que têm dignidade". ${ }^{10}$ Esse é, segundo Rosen, o "núcleo transcendental", e o grande problema a ser enfrentado é o seguinte: mesmo se o admitirmos, não sabemos no que ele ajuda a orientar nossa conduta, i.e., não sabemos como devemos nos comportar.

Consideremos, propõe Rosen, que a dignidade seja algo inerente a mim em virtudedaminha personalidade. Embora seja possível raciocinarinstrumentalmente sobre coisas que têm "preço", minha dignidade, não importa como eu seja tratado, não poderia, segundo o Kant de Rosen, ser aumentada ou diminuída. Isso porque, para Kant, a dignidade é inerente à minha pessoa, não ao meu corpo, e ela não pode ser destruída nem com a minha morte. Como essa compreensão poderia guiar algum tipo de conduta? Em suma, o problema de Michael Rosen (que será também o de Möllers, como veremos) é este: qual normatividade podemos retirar da dignidade? Noutras palavras: como a dignidade guia nossa conduta?

É claro que Kant pensa oferecer, diz Rosen, um arcabouço de guia de ação. Mas a teoria kantiana é muito controversa. Rosen refere que a "visão dominante" entre os kantianos contemporâneos é a de que Kant endossa o "princípio do consenso"; para Rosen, isso não pode ser correto. O que pode ser mais obviamente capaz de ser consentido, pergunta Rosen, do que as pessoas deverem ter o direito de tirar a própria vida? Mas Kant nega esse direito tão ferrenhamente quanto um bispo católico. As mesmas incertezas exsurgiriam, diz Rosen, em relação ao que Kant considera como sendo "deveres pessoais". Para Rosen - obviamente um não kantiano -, é surpreendente que, dadas as dificuldades e controvérsias

10 Rosen traduz direto do alemão. Usei a tradução portuguesa da obra de KANT, Fundamentação da Metafísica dos Costumes. Tradução de Paulo Quintela. Lisboa: Edições 70, 1997. p. 77-8. 
havidas em torno da filosofia moral de Kant, a dignidade tenha-se tornado tão proeminente no discurso político e jurídico. Devemos então supor, diz Rosen, que há algo mais por trás da dignidade que não somente o kantismo.

Isso leva Rosen à sua quarta objeção: a dignidade seria um cavalo de Troia para ataques à igualdade inspirados na religião. A história da dignidade, lembra Rosen, vai de mãos com a história do Cristianismo, o que não é nada estranho, dado que a história do pensamento social ocidental tem sido a do Cristianismo. Três das mais importantes linhas históricas de pensamento sobre o significado da dignidade, diz Rosen, são encontráveis já em Cícero, mas depois do séc. XVIII passam a ser essencialmente cristãs: dignidade como status elevado; dignidade como status do ser humano como tal; e dignidade como forma de discurso que é "dignificado".

Rosen refere que, no séc. XIX, o discurso da dignidade tornou-se bastante significativo no Catolicismo, principalmente sob o pontificado de Leão XIII, para quem a dignidade era parte de uma visão de mundo que vindicava hierarquia Igreja, sociedade, família. Rosen cita a Encíclica Quod Apostolici Muneris, de 1878:

Por isso, assim como no céu quis os coros dos Anjos fossem distintos e subordinados uns aos outros, e na Igreja instituiu graus nas ordens e diversidade de ministérios de tal forma que nem todos fossem apóstolos, nem todos doutores, nem todos pastores (1 Cor 12, 28-30); assim estabeleceu que haveria na sociedade civil várias ordens diferentes em dignidade, em direitos e em poder, a fim de que a sociedade fosse, como a Igreja, um só corpo, compreendendo um grande número de membros, uns mais nobres que os outros, mas todos reciprocamente necessários e preocupados com o bem comum. [grifei]

Para Rosen, nos pontificados tanto de Leão XIII quanto de seus antecessores Pio IX e Pio X, a mensagem central da Igreja Católica era claramente a de que a hierarquia social deveria ser mantida, o que contrariava frontalmente o espírito igualitário da Revolução Francesa. Estranhamente, porém, ressalta Rosen, no final da $2^{a}$ Guerra Mundial, as antes imutáveis verdades do direito natural transmudaram-se em algo bem menos hostil às doutrinas da igualdade social e aos direitos, em comparação com o que se passava no pensamento católico do século anterior. 
É nessa luz, diz Rosen, que devemos apreciar o aparecimento da dignidade nos vários documentos sobre direitos humanos surgidos nos cinco anos posteriores ao fim da Guerra, particularmente a Declaração Universal de Direitos do Homem (1948) e a Lei Fundamental alemã (1949), as quais consagraram a dignidade em posição proeminente, conectando-a com os direitos e com a igualdade. $\mathrm{O}$ art. $1^{\circ}$ da DUDH diz: "Todas as pessoas nascem livres e iguais em dignidade e direitos." O art. 1, ns. 1 e 2 da Grundgesetz é este:

1. A dignidade da pessoa humana é intangível. Respeitá-la e protegêla é obrigação de todo o poder público. 2. O povo alemão reconhece, por isto, os direitos invioláveis e inalienáveis da pessoa humana como fundamento de toda comunidade humana, da paz e da justiça no mundo. [grifei]

Aqui valeria, sempre com Rosen, o alerta de Schopenhauer sobre a vacuidade da dignidade: o que se perderia se simplesmente disséssemos "todos os seres humanos são livres e iguais em direitos"? O caso do texto alemão é mais difícil, porque precisamos explicar duas coisas: (i) como violamos a dignidade humana e (ii) como conectamos a dignidade com "direitos invioláveis e inalienáveis". Mas então retornamos ao problema kantiano.

Rosen, entretanto, sugere, dialeticamente, que tudo isso não seria grande problema, afinal houve, no final da $2^{a}$ Guerra, um acordo entre o humanismo democrático liberal e a Igreja Católica em torno das básicas igualdades e direitos; se a inclusão da dignidade ao lado dos direitos aduz pouco conteúdo à DUDH, ao menos a dignidade serve como expressão de união, e tolerar algum logro é um preço pequeno a pagar por algo tão importante. O próprio Rosen, contudo, entende que o argumento seria demasiado otimista: adotar a dignidade - seja na forma kantiana, seja na católica - deixa em aberto a questão de como eticamente devemos agir na prática, e aqui há acordos e desacordos entre os humanistas democrático-liberais e o catolicismo. Os ferrenhos desacordos na área da bioética refletem hoje, na prática, a falha da dignidade em guiar comportamentos.

Isso leva Rosen à penúltima objeção, denominada "ataque à autonomia". Rosen inicia referindo-se ao artigo da Professora Ruth Macklin, publicado no 
British Medical Journal em 20 de dezembro de 2003 e intitulado "Dignidade é um conceito inútil" (Dignity is a useless concept), no qual a autora entende que a dignidade não tem nenhuma função positiva a cumprir, por ser extremamente vaga e por simplesmente nada acrescentar à compreensão da temática. Esse entendimento, aduz Rosen, foi logo compartilhado por vários autores, em especial pelo linguista e psicólogo Steve Pinker, cujo artigo "A Estupidez da Dignidade" (The stupidity of dignity), publicado em 28 de maio de 2008 na revista The New Republic. Em poucas palavras, Pinker faz eco às críticas de Macklin e sustenta que o conceito de autonomia, entendido como "consentimento informado", é tudo o que a bioética precisa, e a dignidade nada tem a ajudar. Mas será, pergunta Rosen, que a dignidade seria simplesmente uma forma elaborada de dizer "autonomia"?

Essa questão, sustenta Rosen, fica complicada se trouxermos Kant uma vez mais. "Autonomia é pois o fundamento da dignidade da natureza humana e de toda a natureza racional", 11 diz Kant. Ocorre que Kant entende por autonomia algo diferente do que entendem Macklin e Pinker. A ideia destes últimos é a moderna: autonomia é a soberania do self, i.e., essencialmente, a capacidade/ possibilidade de cada um de agir conforme a própria vontade. Não é essa a visão de Kant, diz Rosen. Para Kant, autonomia seria a escolha do nosso eu superior, numênico — seria algo, na verdade, próximo a um dever moral. É dessa visão de autonomia que Kant deriva um dever moral de não cometer suicídio, de não desenvolver suas próprias capacidades.

A visão moderna de autonomia, diz Rosen, não precisa negar a existência de deveres do homem para consigo mesmo, mas certamente nega o direito do Estado de, em nome desses deveres, ignorar as escolhas individuais. Essa visão moderna foi sustentada na famosa "Petição dos Filósofos" ofertada por seis filósofos perante a Suprema Corte norte-americana no caso Planned Parenthood v. Casey, julgado em 1992, no qual se discutia o direito de morrer. A Suprema Corte então expressamente vinculou dignidade pessoal e autonomia para afirmar o direito de as pessoas tomarem suas próprias decisões em questões envolvendo as mais íntimas escolhas pessoais. Em suma, a dignidade foi tratada 11 KANT, Fundamentação da Metafísica dos Costumes. p. 79. 
como sinônimo de autonomia de poder de decidir o que era importante à vida de cada um - no caso, o direito de morrer.

Entretanto, a visão oposta também aparece na teoria do direito e nos tribunais. Rosen cita, em nítido contraste, o conhecido caso francês do lançamento de anão, decidido tanto pelo Conselho de Estado francês quanto pela Corte Europeia de Direitos Humanos exatamente no sentido contrário, i.e., denegando ao anão o direito - consciente e bem informado - de querer participar da atividade de ser arremessado (e com isso ganhar seu sustento). O argumento usado foi este: arremesso de anão é indigno $\rightarrow$ arremesso de anão viola a dignidade dos que participam da atividade $\rightarrow$ dignidade é inviolável $\rightarrow$ o fato de que o arremesso de anão tenha sido uma atividade livremente escolhida pelos participantes não é razão suficiente para permiti-la.

A última objeção de Rosen refere-se à democracia: a dignidade seria utilizada pelas cortes como uma licença ilegítima para invalidar escolhas democráticas. O argumento é simples: a revisão judicial tem sido ligada à "dificuldade contramajoritária", i.e., à dificuldade de aceitar que alguns poucos juízes possam ir contra ao que estabeleceu a maioria dos representantes do povo. Os direitos individuais têm entrado em cena justamente como elemento de proteção contra a "tirania da maioria"; se a dignidade humana é encarada como um valor transcendental ao indivíduo, como uma varinha mágica da qual brotam os direitos, e se não há consenso sobre o que ela significa, então estaria aberta a porta para que alguns poucos juízes invalidem decisões da maioria com base na dignidade humana.

Há interessantes exemplos de invalidações de atos administrativos e legislativos com base na dignidade. O caso do anão julgado pelo Conselho de Estado francês em 1995 é um exemplo. Duas decisões no Tribunal Constitucional alemão sobre o aborto, em 1975 e 1993, também servem aqui de ilustração: a Corte germânica entendeu, com base na dignidade, em limitar a possiblidade de aborto, contrariando as propostas legislativas e as pesquisas de opinião subsequentes, que revelaram um percentual de mais de $60 \%$ de alemães como favoráveis à prática abortiva. 
Ficaríamos melhor sem a dignidade? - pergunta Rosen. A pergunta está mal posta, diz ele. A dignidade está por demais entrincheirada no nosso discurso. 0 que é preciso é exigir dos que empregam a dignidade no discurso público, ao menos uma melhor especificação de sentido do que entendem por dignidade. Estaríamos então em melhor posição para resistir ao uso da dignidade como "uma cloaca na qual partes interessadas pretendem impor suas prescrições morais, as quais carecem de legitimidade do mandato popular".12

\section{A POSIÇÃO DE CHRISTOPH MÖLLERS}

Serei mais breve na exposição da crítica de Christoph Möllers, Professor de Direito Público e Teoria de Direito da Universidade de Berlim, não porque seja menos importante, mas porque ela é mais fácil de ser resumida. O artigo, intitulado "O Triplo Dilema da Dignidade" (The Triple Dilemma of Human Dignity), pretende argumentar sistematicamente contra o uso da dignidade humana em ordenamentos jurídicos que protegem direitos individuais. ${ }^{13}$

Möllers parte de um caso concreto, julgado pela Corte Europeia de Direitos Humanos em 2008, KU vs. Finlândia, para sustentar, em suma (e no mesmo sentido de Rosen), que o conceito de dignidade humana não é dotado de normatividade suficiente para orientar a conduta do cidadão nem a do Estado. Essa tese central é sustentada por três argumentos básicos - daí o título O Triplo Dilema da Dignidade Humana -, que exponho logo a seguir. Antes, relato o caso.

Na Finlândia, alguém (vou chamá-lo de ofensor) postou em site de relacionamentos uma foto e a descrição física de um menino de doze anos (vítima), usando-a como propaganda sexual. O pai da vítima pediu à polícia para identificar o ofensor, mas o provedor da internet recusou-se a fornecer à polícia os arquivos, alegando estar obrigado a observar as leis finlandesas sobre a proteção de dados. Todas as tentativas, da polícia e dos promotores, de

12 ROSEN, Dignity: The Case Against. p. 154.

13 Ver MÖLLERS, Christoph. The Triple Dilemma of Human Dignity. In: McCRUDDEN, Christopher (Editor). Understanding Human Dignity. Oxford: Oxford U. Press, 2013, p. 173187. Procedo da mesma forma: este item (1.2) é retirado integralmente das ideias de Möllers; as notas de rodapé ficam reservadas às citações expressas. 
conseguir identificar o agressor foram infrutíferas nas três esferas judiciais da Finlândia: todas as cortes entenderam, sempre por unanimidade, que não havia base legal para exigir do provedor que prestasse a informação pedida; os crimes que permitiam essa busca de dados não contemplariam o delito em questão; ademais, o crime cometido estaria prescrito.

A Corte Europeia de Direitos Humanos discordou e julgou em favor da vítima, com base no art. $8^{\circ}$ da Convenção Europeia de Direito Humanos, que protege a privacidade e a vida familiar. Para a $\mathrm{CEDH}$, embora o objeto do art. $8^{\circ}$ fosse a proteção dos indivíduos contra a interferência arbitrária das autoridades, a norma veiculada pelo artigo não somente determinava comportamentos negativos do Estado, mas também impunha obrigações positivas de efetivo respeito à vida privada e familiar. A Corte determinou então que a Finlândia providenciasse o arcabouço jurídico necessário que permitisse à polícia identificar o ofensor. ${ }^{14}$ Passemos aos três dilemas de Möllers.

O primeiro envolve a seguinte "questão substancial": a dignidade protege a intimidade privada ou a persona social? Se é um truísmo que o conceito de dignidade humana protege algo que é específico dos seres humanos, é também verdade que muito do que nos faz humanos depende de nossas capacidades sociais: língua, deliberação, crítica, orgulho. Aqui mora um problema cognitivo central: não há linha divisória clara que limite o individual e o social, nem mesmo se o problema envolve deliberação sobre o corpo humano, como no exemplo da obrigatoriedade de colher exame de DNA de suspeitos de crimes sexuais. De alguma forma, é o problema da autonomia versus condição social do homem que se apresenta. E a dignidade pode ajudar ambos os lados: protege a intimidade da vítima de não ser exposta sem consentimento na rede de computador, mas também protege o ofensor de não ter sua vida pessoal potencialmente devassada, o que poderia ocorrer acaso fosse possibilitado o acesso pelo Estado a todos os

14 Embora a linguagem da CEDH jamais invoque expressamente a dignidade humana (que aliás não figura explicitamente dentre os "direitos" na Convenção Europeia de Direitos Humanos), Möllers justifica o uso do caso como paradigma da seguinte forma: "quando tentamos explorar problemas conceituais, não dependemos do uso semântico da dignidade num ordenamento jurídico positivo específico, ao menos não na medida em que podemos argumentar no sentido de que os problemas do nosso caso são usualmente discutidos dentro do estrutura [conceitual] da dignidade humana." MÖLLERS, The Triple Dilemma of Human Dignity. p. 174-5. 
seus dados telemáticos, o que certamente seria necessário fazer para identificar o autor da ofensa. Há, no entanto, um outro e crucial dado: a polícia teria de acessar todos os dados telemáticos do provedor, i.e., poderia haver a devassa de várias vidas privadas, inclusive de terceiros sem nenhuma responsabilidade.

O segundo dilema é a "questão relacional": a dignidade é um direito subjetivo ou valor objetivo? Supondo que a dignidade seja um "direito subjetivo", qual seria a prestação exigível acaso haja a sua violação? Outra linha de questionamento: se a dignidade faz parte do sistema jurídico, e não somente do sistema moral, ela toma a forma de uma regra ou de um princípio, remontando a valores? Não é fácil responder a essas questões segundo o caso paradigma.

Mas há ainda outro aspecto neste tópico: um problema negligenciado da teoria dos direitos humanos é o de como sancionar coerentemente suas violações. Se a dignidade humana é considerada um direito subjetivo particular que goza de posição central no sistema jurídico e inclusive de superioridade em posição hierárquica, não deveria a sua violação merecer maior reprimenda? Se assim deveria ser, os ordenamentos jurídicos não parecem isso refletir, uma vez que a violação de alguns direitos são muitas vezes sancionadas com a simples invalidação do ato; e, em relação à violação da dignidade, se ela é um direito superior em hierarquia, sua violação haveria de corresponder à sanção parecida com a do homicídio. Mas nem o sistema jurídico alemão chega a essa ponto.

O terceiro dilema gira em torno da seguinte "questão prática": a dignidade seria um direito geral sem aptidão para resolver casos específicos. Uma das assunções básicas do discurso acerca da dignidade humana é a de que ela serve a um "acordo teoricamente incompleto", i.e., a dignidade seria uma expressão de consenso para dar curso a razões controvertidas. A história é bem conhecida: ao final de $2^{a}$ Guerra, ocidentais e orientais, capitalistas e comunistas precisavam formular um documento fundado em pontos comuns de compromisso, e a dignidade era a expressão de consenso. Em síntese, todos concordavam que a expressão deveria estar lá, mas ninguém concordava no porquê. Ora, seria difícil que, havendo discordância sobre o significado, a dignidade pudesse ser aplicada de forma incontroversa. 
Em razão disso, não há nada de acidental no fato de que a aceitação universal da dignidade humana não tenha levado, na sua aplicação prática, a resultados comuns; mais, que a sua aplicação seja bastante díspar, até mesmo com significados opostos: alguns Estados aplicam a pena de morte e entendem não violada a dignidade (nos EUA, alguns estados entendem que determinadas espécies de pena capital são "indignas", como a cadeira elétrica); mas outros entendem que a pena capital viola a dignidade; uns entendem que a dignidade humana protege o feto e justifica a pena criminal pelo sistema jurídico, outros que a dignidade a ser protegida pelo mesmo sistema é a da livre escolha da mãe. A questão é esta: como essas contradições podem ser reconciliadas com a ideia de haver um núcleo e uma periferia da dignidade? A resposta de Möllers é desoladora: parece que não podem. E isso porque a ideia de núcleo e periferia não pode ser aplicada se pudermos identificar significados contraditórios dentro do mesmo conceito. Com todas essas contradições, a dignidade humana, conclui Möllers, "definitivamente não é o tipo de norma que nos ajude a prevenir que Estados ou indivíduos ajam de determinada forma". ${ }^{15}$

\section{A PROPOSTA DE DIGNIDADE COMO STATUS — INTER-RELAÇÃO ENTRE DIGNIDADE E IGUALDADE}

Nos últimos anos, o historiador do direito e Professor em Yale James $\mathrm{Q}$. Whitman parece ter plantado o germe da ideia de tratar a dignidade como um status a ser perseguido; ${ }^{16}$ e é o jusfilósofo, teórico político e Professor na NYU Law School e em Oxford Jeremy Waldron quem a vem desenvolvendo com mais cuidado. ${ }^{17}$ Em poucas palavras, trata-se de considerar a dignidade como "posição"

15 MÖLLERS, The Triple Dilemma of Human Dignity. p. 174-5.

16 Ver WHITMAN, James Q. Harsh Justice: Criminal Punishment and the Widening Divide between America and Europe. Oxford: Oxford University Press, 2003; WHITMAN, James Q. The Two Western Cultures of Privacy: Dignity Versus Liberty. Yale Law Journal, v. 113, p. 1151-1221, 2004. WHITMAN, James Q. "Human Dignity" in Europe and in the United States: The Social Foundations. Human Rights Law Journal, v. 25, p. 17-23, 2004.

17 Ver, principalmente, WALDRON, Jeremy. Dignity, Rights and Responsibilities. Arizona State Law Journal. Vol. 43, Issue 4, winter 2011, pp. 1107-36; WALDRON, Jeremy. Dignity, Rights, and Rank (Berkeley Tanner Lectures). Oxford University Press, 2012; WALDRON, Jeremy. How Law Protects Dignity? Cambridge Law Journal, v. 71, n. 1, p. 200-222, March 2012. WALDRON, Is Dignity the Foundation of Human Rights? (January 3, 2013). NYU School of Law, Public Law Research Paper No. 12-73. Disponível em SSRN: 
(rank) superior, i.e., um status ao qual se deve tratar de elevar (leveling up) todos, e não somente alguns, como ocorria desde os romanos nas sociedades não igualitárias.

Se posso escolher uma metáfora de Waldron para sucintamente expressar uma ideia rica em conteúdo, é a de uma sociedade de apenas uma casta - uma casta superior - em que todos os humanos são equiparados a brâmanes:

Todo homem um duque, toda mulher uma rainha, todos titulares de uma espécie de deferência e consideração, a pessoa e o corpo de todos sacrossanto, na forma que os nobres tinham direito a deferência ou na forma que um ataque sobre o corpo ou a pessoa de um rei era considerado um sacrilégio. ${ }^{18}$

Anote-se que Waldron lembra que a ideia de dignidade como status também aparece em Kant, mas não no locus comumente citado (a Fundamentação da Metafísica dos Costumes, como visto acima na crítica de Rosen), mas sim na Metafísica dos Costumes. ${ }^{19}$ Na Metafísica Kant também fala de uma "distribuição de dignidades" e descreve nobreza como uma dignidade que "torna o possuidor, mesmo sem especiais serviços, membro de um status mais elevado", completando que não pode "existir no Estado nenhum homem desprovido de dignidade, pois que tem, pelo menos, a de cidadão". ${ }^{20}$ Depois, em passagem da Metafísica sobre o servilismo, Kant tem mais longa passagem, citada por Waldron:

Não se tornem escravos dos homens. - Não permitam que o vosso direito seja espezinhado por outros. Não contraiam dívidas, em relação às quais não possam prestar garantia plena. Não aceitem benefícios de que possam prescindir [...] Queixar-se e gemer, ou até mesmo gritar por causa de uma dor corporal é já indigno de vós, sobretudo se já estais conscientes de ter sido culpados [...] Ajoelhar-se ou prostrar-se,

http://ssrn.com/abstract=2196074 ou http://dx.doi.org/10.2139/ssrn.2196074. Acesso em: 21 abr. 2015. Exponho a proposta teórica de Waldron noutro artigo, escrito com Cláudia Perrone. Ver GIACOMUZZI, José Guilherme; PERRONE, Cláudia. A ideia de dignidade na obra de Jeremy Waldron (ainda inédito).

18 WALDRON, Dignity, Rights and Responsibilities. p. 1120; WALDRON, Dignity, Rank, \& Rights. p. 34.

19 Ver WALDRON, Dignity, Rank, \& Rights.. p. 24-5. A ideia do parágrafo tomo toda de Waldron. Usarei aqui sempre a tradução portuguesa de José Lamego para a obra de KANT, Immanuel. A Metafísica dos Costumes. Tradução de José Lamego. Lisboa: Fundação Calouste Gulbenkian, 2005 [1797]. Deixarei entre parênteses e precedido de $A k$ a pág. da edição da Academia das Ciências da Prússia (Akademie Textausgabe).

20 KANT, A Metafísica dos Costumes. p. 204-5 (Ak 328-9). 
ainda que seja para manifestar deste modo a veneração pelos objetos celestes, é contrário à dignidade humana [...]". ${ }^{21}$ [grifei]

É justamente essa ideia de status que Waldron quer resgatar. E é essa a proposta que me parece promissora. Ela é complexa e não será aqui esmiuçada, mas simplesmente assumida como um germe razoável a dar à dignidade um conteúdo mais palpável, bastante próximo à igualdade.

Nas palavras de Waldron, "dignidade e igualdade são interdependentes". ${ }^{22}$ E, embora Waldron nesta parte do seus escritos não cite expressamente Kant, parece-me que poderia fazê-lo com proveito: no mesmo parágrafo da Metafísica sobre o servilismo, mas um pouco antes da passagem acima citada, Kant se refere à dignidade como "valor intrínseco absoluto" que "obriga todos os demais seres racionais do mundo a guardarem-Ihe [a ele homem] respeito, podendo medir-se com qualquer outro desta espécie e valorar-se em pé de igualdade."23 [grifei]

Por fim, anote-se somente que, na proposta teórica de Waldron, a dignidade não opera sempre da mesma forma: ela pode operar tanto como fundamento de alguns (não todos) os direitos como quanto conteúdo de direitos. ${ }^{24}$ Tentarei sugerir como isso poderia auxiliar na busca de encontrar sentido nas decisões do STF, tarefa que empreendo a seguir.

\section{O STF E A DIGNIDADE EM MATÉRIA DE DIREITO ADMINISTRATIVO}

A busca no STF por decisões que contenham as expressões "dignidade humana" ou "dignidade da pessoa humana" trazia, na última semana de maio de 2014, exatos 260 documentos. As que dizem direta ou indiretamente com o direito administrativo não chegam a vinte, e somente onze delas serão aqui tratados. Esse corte é menos arbitrário que o anterior: eu tratarei somente dos acórdãos, e não de decisões monocráticas, e deixarei de fora os acórdãos que mencionam a dignidade apenas lateralmente. ${ }^{25}$

21 KANT, A Metafísica dos Costumes. p. 369-70 (Ak 436).

22 WALDRON, Dignity, Rank, \& Rights. p. 55.

23 KANT, A Metafísica dos Costumes. p. 367 (Ak 435).

24 WALDRON, Dignity, Rank, \& Rights. p. 17.

25 São excluídos deste estudo acórdãos que (1) só trazem a expressão "dignidade (da pessoa) 


\section{DIGNIDADE HUMANA E CONCURSO PÚBLICO}

Quem conhece a jurisprudência do STF sabe que desde o final do século passado começou a ser discutida uma alteração da interpretação da Corte no que toca ao direito subjetivo à nomeação do candidato aprovado em concurso público. O STF entendeu uma vida toda que o candidato aprovado em concurso público teria direito subjetivo somente a não ser preterido por outro candidato também aprovado mas pior colocado no certame, isso se a Administração Pública entendesse de nomear algum candidato. Essa nomeação, entretanto, estaria compreendida no poder discricionário da Administração, i.e., a nomeação do candidato se daria ou não segundo a oportunidade e a conveniência da Administração; assim, o candidato aprovado teria somente expectativa de direito. ${ }^{26}$

Ocorre que alguns ministros do STF passaram a entender que o candidato aprovado tem sim direito subjetivo à nomeação até o número de vagas oferecido pelo edital do concurso. Essa questão teve repercussão geral reconhecida, e ainda não julgada, já em 2009, ${ }^{27}$ mas desde antes disso há decisões do STF entendendo que quem faz concurso público e tira, por exemplo, o $20^{\circ}$ lugar, tem sim direito subjetivo a ser nomeado acaso o edital do certame tenha previsto no mínimo vinte vagas. É a história dessa mudança - e o papel que a dignidade joga nessa mudança - que vou tentar contar.

humana" desacompanhada de qualquer análise, como por exemplo nos Agravos Regimentais nos RE 648.622/DF, j. em 20.11.2012, e RE 632.644, j. em 10.04.2012, ambos unânimes e pela $1^{\text {a }}$ Turma, nos quais se encontra a mesma referência genérica de que a "dignidade da pessoa humana" é fundamento do Estado Democrático de Direito; ou que (2) foram captados na busca do sistema em razão de terem citado alguma obra em cujo título apareceu o termo, como por exemplo no RE 579.915-4/RN, j. em 20.08.2008 pelo Pleno (acórdão sobre nepotismo, citando a obra de Ana Paula de Barcelos intitulada A Eficácia Jurídica dos princípios constitucionais: o princípio da dignidade da pessoa humana. Renovar, 2008); ou que (3) usam a ideia de dignidade de forma quase vulgar para referir-se a fatos que todos concordariam serem afrontosos à "dignidade humana", como os serviços de saúde em alguns hospitais, como por exemplo o caso refletivo no Agravo Regimental no AI 850.017/RJ, j. em 11.09.2012 à unanimidade pela $2^{a}$ Turma (acórdão que nega recurso do Município do RJ contra acórdão do TJ local que determina à Administração Pública que dotasse o Hospital Salgado Filho de condições mínimas para o tratamento "digno" do cidadão).

26 A melhor e mais clara exposição da antiga posição do STF encontra-se no voto do Min. Néri da Silveira no RE 229.450-8/RJ, j. 10.02.2000, Pleno, acórdão referido no texto logo na sequência.

27 RG no RE 598.099-5/MS, rel. Min. Gilmar Mendes, j. 24.04.2009. 
A mudança de posição começa a operar-se por meio de alguns votos vencidos que surgem na virada do século. O debate travado nos acórdãos que interessam aqui tinha como pano de fundo a validade da norma contida no inc. VII do art. 77 da Constituição do Estado do Rio de Janeiro, que basicamente criava, de forma expressa, direito subjetivo à nomeação, em 180 dias, ao cargo público para candidato aprovado dentro no número de vagas obrigatoriamente constante do edital. ${ }^{28}$ Ao criar esse direito ao cidadão, a CE do RJ ia aparentemente de encontro à então dominante jurisprudência do STF que, ao menos desde a CF 1946, entendia, como já referi, que o cidadão não tem direito subjetivo à nomeação, mas somente expectativa de direito, e que a Administração tem discricionariedade para optar por nomear ou não o candidato. A questão em jogo era esta: poderia a CE do RJ conferir ao cidadão o direito subjetivo de ser nomeado (no caso, em 180 dias)?

Em no mínimo três julgados o Pleno STF enfrentou o tema e respondeu negativamente à pergunta, sempre por maioria de votos: são o RE 190.264-7/RJ, julgado em 10.02.2000; o RE 229.450-8/RJ, cujo julgamento iniciou em 04.11.1999 e terminou em 10.02.2000; e finalmente a ADIn 2.931-2/RJ, julgada em 24.02.2005. ${ }^{29}$ Em todos esses casos o STF manteve sua tese clássica, assim resumida pela Corte: a Constituição Federal esgotava a matéria conferindo ao candidato tão-somente dois direitos subjetivos: (1) o direito implícito de ser recrutado segundo a ordem de classificação no certame e dentro do prazo do concurso; e (2) o direito explícito de precedência de todos os candidatos aprovados em concurso anterior sobre os candidatos aprovados em concurso posterior. Ambos os direitos, frisou o STF, estariam condicionados ao querer discricionário da Administração Pública. Por isso a CE do RJ não poderia determinar à Administração Pública um prazo (180 dias, no caso) para nomear os candidatos aprovados. O que estava realmente em jogo e quais os argumentos do STF para manter suas teses é o que importa aqui. ${ }^{30}$

28 Eis o texto em discussão: "VII - a classificação em concurso público, dentro do número de vagas obrigatoriamente fixado no respectivo edital, assegura o provimento no cargo no prazo máximo de cento e oitenta dias, contado da homologação do resultado".

29 Os dois primeiros declararam incidentalmente a inconstitucionalidade do referido inc. VII do art. 77 da CE do RJ, e o último acórdão declarou a inconstitucionalidade em abstrato, invalidando a norma e retirando-a definitivamente do ordenamento jurídico.

30 O que segue é a minha interpretação da forma com que foram construídos os argumentos do STF, e não uma descrição desses argumentos; também não sigo a sequência cronológica dos argumentos do STF, e tampouco analiso os acórdãos nessa ordem. Estou tentando, a bem da verdade, ler as decisões sob a sua "melhor luz", embora eu discorde tanto da forma 
O argumento central, construído ao longo dessas decisões, parece ser o de que a CF teria esgotado a matéria nos seus art. 37, I IV, não deixando margem a tratamento diferente nas Constituições dos Estados-membros ou normas infraconstitucionais. O STF também retirou do texto da CF norma que dá à Administração Pública o poder discricionário de nomear ou não os candidatos aprovados, norma essa que faria parte da estrutura federativa do Estado. Neste sentido, o Ministro Carlos Ayres Britto, relator da ADIn 2.931, julgada em 2005, referiu que essa norma seria cláusula pétrea, e que o dispositivo da CE do RJ feria não só a forma federativa de Estado mas também a separação de poderes (art. 60, § 4, I e III, CF).

Alguns ministros, porém, discordaram - e são os argumentos discordantes que interessam -, porque eles passaram a balizar o entendimento atualmente predominante no STF, que defende posição diversa, como já referido. O Ministro Sepúlveda Pertence, por exemplo, em curtíssimo voto ainda em 04.11.1999 no RE 229.450, rechaçou o argumento da discricionariedade com um raciocínio simples: a CE do RJ teria simplesmente antecipado o juízo discricionário da necessidade do preenchimento dos cargos para o momento do edital, o qual vincularia o administrador. O Ministro Octávio Gallotti, também no RE 229.450, entendeu que o direito subjetivo à nomeação não nascia do edital, mas que a Constituição ou a Lei estaduais poderiam sim estabelecer esse direito sem ferir a CF.

Ministro Marco Aurélio, que era o Relator originário do RE 190.264, pediu vista no referido RE 229.450 e levou os feitos a julgamento conjunto no mesmo dia 10.02.2000. Veio dele a argumentação mais contundente do lado dos ministros então vencidos: a CE do RJ estava a dar aplicação ao princípio da moralidade administrativa "em homenagem à fé daqueles que acreditaram na seriedade da proposta, abandonando a vida normal para dedicarem-se com exclusividade [...] ao concurso em si". A Corte, entretanto, seguiu caminho diverso.

Somente cinco anos mais tarde, no seu voto vencido proferido na ADIn 2.931, é que o Ministro Marco Aurélio invoca expressamente a dignidade: o voto começa

quanto do conteúdo da maioria dos argumentos vencedores e vencidos. Não é, contudo, a minha interpretação que importa aqui, nem importa como eu julgaria os casos; quando minha opinião importar para o ponto central deste ensaio (a análise do papel da dignidade nas decisões do STF), isso ficará claro no texto, ou ao menos essa é minha intenção. 
com a afirmação de que o "texto da Constituição do Estado do Rio de Janeiro [...] homenageia um fundamento básico da República: a preservação da dignidade do homem". ${ }^{31}$ Para o Ministro, se o edital do certame anuncia um determinado número de vagas, a Administração Pública tem o dever de preenchê-las. E agora a linguagem passa a ser mais contundente: "A Administração Pública não pode brincar com o cidadão, convocando-o para um certame e depois, simplesmente, deixando esgotar o prazo de validade do concurso sem proceder às nomeações". Com esses argumentos, o Ministro Marco Aurélio propunha mais uma vez abandonar a jurisprudência do STF para conferir direito subjetivo à nomeação aos candidatos aprovados em concurso público. Só que desta vez, em 2005, ele lança mão da dignidade humana, o que não ocorrera em 2000.

Essa mesma estratégia argumentativa foi apresentada - outra vez sem sucesso - no Ag. Reg. no AI 501.573-1/DF, julgado pela $1^{\text {a }}$ Turma em 12.04.2005, ficando outra vez vencido o Min. Marco Aurélio, que novamente fez questão de frisar que a questão do direito subjetivo à nomeação passa pelos "fundamentos da própria República: a dignidade do homem". Não sendo conferido o direito subjetivo ao candidato, a Administração estaria "a brincar com o cidadão".

Três anos mais tarde, em 16.09.2008, no julgamento do RE 227.480-7/RJ, a tese do direito subjetivo fez-se enfim vencedora, mas agora na $1^{\text {a }}$ Turma do STF. O caso tratava exatamente da existência ou não de direito subjetivo à nomeação de candidato aprovado em concurso para Oficial de Justiça Avaliador do Quadro Permanente da Sessão Judiciária do Estado do Rio de Janeiro; dois ministros entenderam não haver direito subjetivo à nomeação, mas os três restantes entenderam o contrário. Do voto do Min. Marco Aurélio, sucinto, vê-se o mesmíssimo raciocínio anteriormente exposto: "simplesmente atinge a dignidade do homem anunciar-se um concurso público, sinalizando-

31 Digo inequivocamente porque no RE 192.568-0/PI, 2a Turma, j. em 23.04.1996, decisão por maioria, o Min. Marco Aurélio, que relatava o processo, já havia feito menção à dignidade para resolver caso que envolvia direito à nomeação em concurso público. São duas as razões para não incluir esse caso como o pioneiro, nem analisá-lo: (1) a invocação da dignidade aparece mais en passant e sem função definida (em meio a longa justificativa, vem dito que "[e]m um Estado Democrático de Direito, exsurge a constância na manutenção da dignidade do homem, exigindo, por isso mesmo, postura exemplar [do Estado]"; (2) o próprio Relator fundamenta longamente o voto em vários princípios: legalidade, moralidade, impessoalidade, sem nada referir sobre a dignidade. 
se a necessidade de preenchimento de vagas e, existentes as vagas, o Estado simplesmente não preenchê-las. Não posso conceber isso." ${ }^{32}$ Desde então, a tese antes vencida passou, nalguns casos, dependendo da composição do STF e da Turma, a ser vencedora.

O que importa destacar de toda essa história, que foi propositadamente longa, é que nenhum outro ministro do Tribunal ofereceu nem eco nem repúdio às insistentes provocações do Min. Marco Aurélio ao argumento de que estaria violada a dignidade humana como fundamento da República. Na verdade, a dignidade parece funcionar mais como obiter dictum ou como retórica apelativa. Como diria Michael Rosen, nada perdemos se a tirarmos do debate. Na questão em tela, isso é inteiramente verdadeiro. Explicito.

Todo o debate havido entre os ministros girou em torno da existência ou não de direito subjetivo à nomeação versus poder discricionário da Administração. Mais importante, a tese do Ministro Marco Aurélio (e outros), antes vencida, de que há direito subjetivo à nomeação parece ser mais consistentemente sustentada sem o apelo à dignidade, bastando a invocação do princípio da confiança e da boa-fé objetiva, ou, como eu prefiro, da moralidade administrativa. ${ }^{33}$ Aliás, o próprio Min. Marco Aurélio invocou, como vimos, a moralidade administrativa em casos anteriores, sem apelar à retórica da dignidade, a qual nada tem a fazer na temática.

Alguém dirá que ferir a moralidade administrativa (ou a confiança do administrado ou sua boa-fé) já é ferir a dignidade humana, talvez porque a dignidade seria um sobreprincípio, ${ }^{34}$ ou talvez uma "metanorma". ${ }^{35}$ Isso não foi dito pelo Min. Marco Aurélio, mas suponhamos uma tal proposta, i.e., a dignidade como sobreprincípio, ou como compondo outros princípios, ou sendo "superior" a todos eles. Ocorre que, no caso específico, não parece haver, salvo se estendermos demais os significado dos vocábulos, qualquer linha genealógica entre moralidade administrativa, boa32 Citação expressa do voto proferido no RE $227.480-7 / R$ J, j. por maioria em 16.09 .2008 pela $1^{\text {a }}$ Turma, rel. para o acórdão Min. Cármen Lúcia. A decisão foi dada por três votos a dois, e nem os demais votos majoritários nem os votos vencidos fizeram qualquer referência à dignidade.

33 Para a aproximação da boa-fé objetiva, confiança e moralidade, ver GIACOMUZZI, José Guilherme. A Moralidade Administrativa e a Boa-Fé da Administração Pública: o conteúdo dogmático da moralidade administrativa. 2.ed. São Paulo: Malheiros, 2013.

34 Parece ser essa a tese, um tanto confusa, de JUSTEN FILHO, Curso de Direito Administrativo. p. 179-80. O autor refere que a dignidade humana é "transcendental".

35 Ver item 2.3. 
fé e confiança, de um lado, e dignidade humana, de outro.

A premissa do Min. Marco Aurélio supõe que a Administração Pública levou a efeito concurso público ou (i) para deliberadamente não chamar os candidatos ou (ii) sem cuidado de aquilatar se precisava mesmo dos servidores. E que isso seria "brincar com o cidadão" e trair sua confiança, ferindo sua dignidade. Não concordo, por no mínimo duas razões.

Primeiro, porque o próprio sistema jurídico - com o aval do próprio STF dava à Administração o direito de realizar concurso e discricionariamente não chamar candidatos. Se no caso a Administração "brincou" com o cidadão, o ato administrativo é nulo, por desvio de finalidade (art. $2^{\circ}$, parágrafo único, "e", Lei 4.717/65), e nesse caso poderíamos concluir, com razão, que estaríamos diante de uma imoralidade administrativa, uma vez que a moralidade administrativa prevista como "bem jurídico" protegido no art. 50, LXXIII, da CF sempre me pareceu a constitucionalização da teoria francesa do desvio de finalidade. ${ }^{36}$ Mas nada disso consta do voto, e nem - mais importante - a dignidade tem algum papel a jogar aqui. Ela é, parece-me, desnecessária (assim foi, ao menos, para todos os demais ministros).

Segundo, porque, seguindo o raciocínio do ministro, poderíamos também inferir que toda a vítima de estelionato (art. 171 do Código Penal brasileiro) tem sua "dignidade" violada, ou mesmo que a quebra de confiança ou boa-fé no direito privado equivaleria à violação da dignidade.

Parece-me que cairíamos na satírica crítica lembrança de Rosen: "quando todo mundo é alguém, joão-ninguém é qualquer um", i.e., se a dignidade é tudo, então ela é nada ao mesmo tempo - em suma, ela não tem função para além da ornamental. Argumentar assim é rebaixar a dignidade, e não exaltá-la. E repito: a dignidade não parece contribuir em nada para o julgamento dos feitos, nem sequer foi referida por qualquer dos demais ministros do STF.

Seja como for, a vinculação entre dignidade humana, segurança jurídica, boa-fé e moralidade administrativa foi feita de forma mais sutil e quiçá

36 Ver GIACOMUZZI, A Moralidade Administrativa e a Boa-Fé da Administração Pública. p. 23194. 
interessante em no mínimo duas outras oportunidades pelo STF, o que nos levará a outro tópico.

\section{DIGNIDADE HUMANA E DEMORA DE APRECIAÇÃO DE APOSENTAÇÃO PELOS TRIBUNAIS DE CONTAS - SEGURANÇA JURÍDICA E MORALIDADE}

Nos Mandados de Segurança 25.116/DF, julgado por maioria pelo Pleno em 08.09.2010, e 28.720/DF, julgado à unanimidade pela $2^{\text {a }}$ Turma em 20.03.2012, ambos de Relatoria do Ministro Ayres Britto, o STF fez expressa vinculação entre dignidade humana, segurança jurídica, boa-fé e moralidade.

Mais especificamente, foi dito de forma expressa - e posto na ementa do acórdão - que o princípio da segurança jurídica é "projeção objetiva do princípio da dignidade da pessoa humana e elemento conceitual do Estado de Direito". Essa premissa, somada à da "lealdade, um dos conteúdos do princípios constitucional da moralidade administrativa (caput do art. 37)", fazem com que seja necessário, diz o STF, "se reconhecer [...] certas situações jurídicas subjetivas ante o Poder Público". Nos casos concretos, a "situação" a ser reconhecida foi o direito subjetivo do cidadão a ver a legalidade do ato de aposentadoria apreciada pelos Tribunais de Contas no prazo de cinco anos. Findo esse prazo, passa o cidadão a ter o direito subjetivo de exercitar o direito ao contraditório e à ampla defesa nos processos perante o Tribunal de Contas que aprecia a sua aposentação. Antes disso, não há esse direito, por tratar-se de relação administrativa interna entre Poderes, i.e., antes disso o TC pode apreciar o ato concessivo de aposentadoria sem dar ao agente público ciência do procedimento.

Como sabemos, dentre as atribuições dos Tribunais de Contas está a de "apreciar, para fins de registro, a legalidade [...] das concessões de aposentadorias" (art. 71, III, CF). A rigor, os atos de aposentadoria dos agentes públicos são exemplos 
clássicos de atos complexos, i.e., que só se aperfeiçoam com a integração da última vontade, ou seja, no caso, somente com o registro no Tribunal de Contas. Pois o STF disse, em apertado mas suficiente resumo, que a demora de mais de cinco anos em apreciar a legalidade da aposentadoria do agente público fere a segurança jurídica, a qual, na linguagem do Min. Ayres Britto, é a "projeção objetiva da dignidade humana", bem como a moralidade administrativa, da qual decorre o dever de lealdade. $\mathrm{O}$ administrado não pode esperar tanto tempo pela resposta do Estado: ele confia de boa-fé que o Estado em cinco anos haverá de dar-lhe uma resposta.

Não houve grande debate na Corte sobre a inserção da "dignidade humana" no argumento (dado relevante: o acórdão tem 149 laudas), e é fácil ver que ela poderia ter sido, mais uma vez, retirada do raciocínio sem qualquer perda de significado ou de clareza. Aliás, a prova disso está nos próprios acórdãos referidos, os quais citam como referência o MS 24.268-0/MG, j. em 05.02.2004, decisão por maioria, relator Ministro Gilmar Mendes, no qual o mesmíssimo tema foi debatido, tendo chegado o STF à idêntica solução e usado, no seu raciocínio, os mesmos princípios da confiança, proteção à segurança e Estado de Direito, mas absolutamente nada dizendo sobre a dignidade. O que choca o leitor atento é que as ementas e as partes dos acórdãos de relatoria do Ministro Ayres Britto são quase idênticas à ementa e à parte do acórdão de relatoria do Ministro Gilmar Mendes. A diferença é que o Min. Ayres Britto ornamentou os feitos de sua relatoria com a menção expressa à dignidade.

É ainda e por fim importante notar que o Ministro Gilmar Mendes, em seu voto vista no MS 25.116, relata longamente o feito, as conclusões e os fundamentos do voto do Min. Ayres Britto, mas nem aí ele menciona a dignidade. Consciente ou inconsciente, a cautela do Min. Gilmar Mendes em não fazer qualquer referência à dignidade, mesmo quando relata o voto do relator, contrasta nitidamente com a vontade, consciente ou inconsciente, não importa, do Min. Ayres Britto em exaltar a dignidade.

Mas talvez possamos retirar da linguagem do voto (ou melhor, da frase) do Min. Ayres Britto algo mais que ornamento. Segundo a linguagem do Min. Ayres 
Britto, a dignidade seria algo a ser "protegido" pela segurança jurídica. Embora o voto não contenha nenhum desenvolvimento nesse sentido, a ideia que parece subjacente é a de que a dignidade é um bem, e não o fundamento do direito. Aqui parece haver espaço para a ideia de Waldron, brevemente referida no item 1.3 supra, de que a dignidade não opera somente como fundamento de (alguns) direitos, mas também como conteúdo de direitos. O problema seria saber qual direito conteria a dignidade neste caso. Seria o "direito à razoável duração do processo" (art. 50, LXXVIII, CF)? É difícil dizer que esse direito contenha a ou sirva para proteger um status normativo superior do cidadão, i.e., sua dignidade, como, por exemplo, o direito a não ser torturado (art. $5^{\circ}$, III, CF) ou mesmo o direito a não ser processado sem o devido processo (art. $5^{\circ}$, LIV, CF), instrumentos pelo qual podemos entender que o Direito se utiliza para proteger a dignidade. ${ }^{37}$

\section{DIGNIDADE HUMANA E SERVIÇO PÚBLICO DE TRANSPORTE COLETIVO DE PASSAGEIROS -METANORMA? IGUALDADE?}

Em 08.05.2008 o Pleno do STF julgou a ADIn 2.649-6/DF, que tratava de apreciar a constitucionalidade da Lei Federal 8.899, de 1994, a qual concedia passe livre no sistema de transporte coletivo interestadual às pessoas portadoras de deficiência comprovadamente carentes. Por nove votos a um, o STFjulgou improcedente o pedido da ABRATI, entidade privada representante das transportadoras de passageiros. ${ }^{38}$

O voto da Relatora, Ministra Cármen Lúcia, elogiado e endossado pela quase totalidade dos ministros, é uma ode à solidariedade social e à teoria francesa do serviço público; a Ministra inclusive cita, em francês e sem tradução, a obra de Gilles Guglielmi e Geneviève Koubi, Droit du service public, de 2000, um dos mais completos estudos sobre o tema na França. ${ }^{39}$

37 Ver WALDRON, How Law Protects Dignity? p. 203.

38 Este acórdão serviu de paradigma para caso análogo, o Ag. Reg. no AI 847.845/RJ, j. em 11.12.2012 à unanimidade pela $1^{\text {a }}$ Turma, rel. Min. Luiz Fux, no qual se discutia a gratuidade de transporte para deficientes mentais. Esse acórdão simplesmente reproduziu os fundamentos da ADIn 2.649, comentada no texto.

39 Desde 2007 o leitor tem edição mais recente a consultar. Ver GUGLIELMI e KOUBI, GUGLIELMI, Gilles J.; KOUBI, Geneviève. Droit du service public. 2. ed. Paris: Montchrestien, 2007. É tradição do STF (e de outros tribunais) citar em francês (e outras línguas estrangeiras) e não traduzir. Não quero exagerar na crítica e por isso não vou nem de longe sugerir que deixar de traduzir ao português a passagem escrita idioma estrangeiro fere a "dignidade 
É possível resumir assim os argumentos do longo voto: como a CF prevê que o Estado deve concretizar os valores do bem-estar, da justiça social, da sociedade fraterna, pluralista e sem preconceitos; como a mesma CF assegura a igualdade material de todos; como dentre os objetivos da República está o da construção de uma sociedade livre, justa e solidária, sem discriminações etc., decorreria da CF, no entender da Ministra, "o princípio jurídico da solidariedade"; soma-se a isso o fato de que o serviço público é marcado e norteado mais pelo interesse público do que pelo interesse particular, o que dá ao Estado o "dever constitucional incontornável" de moldar as estruturas públicas para o "atingimento dos fins estabelecidos e das ordens que nele [Estado] atuam"; e, por fim, como tanto os fins como as ordens - e aqui o que nos importa - "têm o seu fundamento da busca incessante da dignificação do ser humano, na igualação jurídica de todas as pessoas pela oferta igual de oportunidades na participação da vida social" [grifei], então não haveria inconstitucionalidade alguma em impor às transportadoras a gratuidade no transporte de pessoas deficientes.

Este voto merece atenção e parece conter um germe de razoável sentido à dignidade: de forma clara, a Ministra quis "dignificar" os deficientes por meio da interpretação de que é constitucionalmente válida a gratuidade de passagens de ônibus intermunicipais. Qual o sentido de "dignidade" aqui? Da linguagem parece claro o propósito que a Min. Cármen Lúcia viu na lei sob julgamento: o de elevar o status dos deficientes carentes (a "igualação jurídica", nas palavras da Min. Cármen Lúcia). O aplauso de Waldron seria pleno, ao menos no que toca à identificação do sentido e do papel que a dignidade teve no propósito da lei. Antes de explorar esse viés, contudo, faço alguns comentários contra o pano de fundo crítico.

Sob esse ponto de vista crítico, a fundamentação do voto da Relatora permite concluir que qualquer serviço público poderia ser gratuito para deficientes comprovadamente carentes, desde que houvesse lei assim instituindo. No entanto, se assim fosse, a dignidade poderia ser utilizada para qualquer propósito humana" dos jurisdicionados que não leem em francês (a esmagadora maioria da população brasileira); mas isso me parece um comportamento que dá ares de status "superior" à linguagem do STF, para dizer o menos. Quem quer igualar não pode supor que escrever em francês ajudará a elevar o status dos que não leem em francês. Curiosamente, a própria CF dispõe expressamente, no art. 13, que "A língua portuguesa é o idioma oficial da República Federativa do Brasil". 
"igualador" por meio de lei, sobrepondo-se aprioristicamente sobre todo e qualquer outro "princípio". Seria então a dignidade uma "metanorma"?

Essa visão é encontrada no mesmo julgado, no voto do Ministro Ricardo Lewandowski: "A nossa Constituição, como sabemos, em homenagem ao princípio ou, na verdade, da verdadeira metanorma da dignidade humana, foi extremamente pródiga no que diz respeito à proteção do deficiente físico" [grifei]. Logo depois, o ministro cita três artigos da CF: arts. 23, II; 227, §§ $1^{\circ}$ e 20; e 244 que embasariam sua tese.

É difícil saber qual o significado de "metanorma" no voto. Façamos um esforço analítico e tomemos uma proposta teórica desenvolvida entre nós, a de Humberto Ávila, para tentar elucidar o argumento: segundo essa proposta dogmática, metanormas seriam "normas de segundo grau", "normas sobre a aplicação de outras normas", i.e., seriam "postulados", os quais na verdade "estabelecem a estrutura de aplicação de outras normas, [os] princípios e [as] regras". 40 Segundo esse entendimento, "sempre há outra norma por trás da aplicação [dos postulados] da razoabilidade, da proporcionalidade e da excessividade"41. Voltando ao acórdão: será que a dignidade teria sido tratada (talvez indiretamente, pela Min. Cármen Lúcia, mas diretamente, pelo Min. Lewandowski) como uma norma estruturante da aplicação de outra norma?

Penso que não. A proposta teórica da metanorma como norma estruturante de princípios e regras é uma proposta metodológica acerca do como devam ser aplicadas outras normas, sobre quais as relações e as vinculações entre "elementos (bens, interesses, valores, direitos, princípios, razões)" ${ }^{42}$ Nessa proposta não parece haver espaço para a dignidade como "norma estruturante". Aliás, essa mesma proposta teórica apresenta a dignidade como princípio violado no caso em que o STF declarou inválida, porque desproporcional, ordem judicial para submissão do paciente a exame de DNA (1 ${ }^{a}$ Turma, HC 76.060-SC, j. 31.03.1998). O princípio da dignidade teria sido violado, "na sua inter-relação horizontal com os princípios da autodeterminação da personalidade e da universalidade da 40 Tomo os conceitos de "metanorma" e "postulados" a ÁVILA, Humberto. Teoria dos Princípios. 15.ed. São Paulo: Malheiros, 2014, p. 175 e ss.

41 ÁVILA, Teoria dos Princípios. p. 180.

42 ÁVILA, Teoria dos Princípios. p. 184. 
jurisdição, que deixaram de ser aplicados adequadamente". ${ }^{43}$

Mas pode, claro, o Min. Lewandowski ter usado "metanorma" noutro sentido, por exemplo, como algo "superior" ou talvez "fundante" de outras normas, no sentido de ser a dignidade um "valor maior". Aceitemos essa premissa e, embora o voto não indique esta direção de forma explícita (não seria difícil fazê-lo, uma vez que essa posição parece ser sustentada por parte da doutrina nacional), ${ }^{44}$ assumamos a seguinte linha argumentativa: a dignidade humana é uma metanorma que fundamentaria tanto o dever do Estado de proteger os deficientes físicos quanto os direitos desses deficientes a serem protegidos pelo Estado. O problema deste raciocínio é que não fica claro que direitos a "metanorma" fundamentaria. Temos aqui duas possibilidades: (i) todos os direitos; (ii) alguns.

Sigamos a primeira possibilidade: se a dignidade fundamenta todos os direitos, por qual razão ela não fundamentaria o direito oposto em questão, o da livre iniciativa, que aliás aparece na CF 1988 tanto como princípio que fundamenta a ordem econômica (art. 170, caput) quanto no mesmo artigo da dignidade humana como "fundamento da República" (art. $1^{\circ}$, IV)? Neste caso, por que razão o Min. Lewandowski pinçou somente o "fundamento" da dignidade, e não o da livre iniciativa? Cairíamos no mesmo problema de normatividade identificado por Rosen e Möllers: se a dignidade é uma "metanorma" que fundamenta tanto o direito dos deficientes quanto a liberdade de comércio, então ela é imprestável como regra normativa. Para usar a linguagem corrente, teríamos que ver qual direito tem "mais peso" por meio de um balanceamento entre "dignidades"? E nenhum balanceamento foi feito no voto.

Sigamos agora a segunda possibilidade, i.e., a dignidade fundaria somente alguns direitos (humanos ou fundamentais). Para além do fato de absolutamente nada no acórdão indicar fosse essa a intenção do Min. Lewandowski, é claro que a argumentação agora desborda do dogmático-jurídico para o filosófico: nada na CF ou no ordenamento jurídico brasileiro sugere isso. Mas a possibilidade, como já referido anteriormente, não é estranha a filósofos que se têm dedicado ao estudo dos direitos humanos e da dignidade. Penso que vale a pena explorála, ainda que brevemente, porque aqui talvez haja um germe de racionalidade 43 ÁVILA, Teoria dos Princípios. p. 176-7.

44 Ver notas 5 e 34 supra. 
argumentativa, ou pelo menos possamos escapar da crítica de do "quando todo mundo é alguém, joão-ninguém é qualquer um".

Partindo da premissa de que não há outra opção para os filósofos, teóricos do direito e da política senão desenvolver, influenciar e completar o discurso dos direitos humanos, ${ }^{45}$ o filósofo James Griffin sustenta haver largo consenso entre os filósofos que o direito a "férias remuneradas periódicas" (previsto no art. 24 da Declaração Universal dos Direitos do Homem, de 1948) não é um "direito humano" no mesmo sentido do que o direito à liberdade de expressão. ${ }^{46}$ É essa também a visão de Waldron, para quem a dignidade humana, como antes mencionei, pode ser fundamento de alguns direitos (como por exemplo o direito a não ser torturado, ou preso ilegalmente), mas não de outros (o referido direito às férias remuneradas).

Pois bem, aqui é o momento de recuperar o argumento antes suspenso quando da análise do voto da Min. Cármen Lúcia na ADIn 2.649-6/DF. É possível, como eu referi antes, emprestar ao seu raciocínio o sentido de que ela estaria querendo "elevar" a dignidade, i.e., a posição dos portadores de deficiência carentes a outro patamar. A mencionada igualdade material referida no voto convida essa interpretação, e, também como já vimos, a posição de dignidade como status está diretamente relacionada à igualdade. Mas o fato de se pretender dignificar - elevar o status, igualar - certa categoria de pessoas (deficientes carentes) não encerra a questão do ponto de vista da constitucionalidade da norma examinada.

Olhemos a questão pelo prisma da igualdade: qual o critério igualador? Seria o de igualação de status entre os portadores de deficiência e os não portadores? Se é assim, poderíamos questionar se a gratuidade da tarifa é a melhor forma de promover a igualdade, ou, se quisermos, dignificar as pessoas portadoras de deficiência. É que, neste caso específico, dignificar uns será feito a custa de outros (os que financiarão a tarifa não paga). A ideia de status não parece permitir a conclusão, tout court, que para que o status de um grupo seja elevado, outros tenham que pagar por isso.

45 Ver GRIFFIN, James. On Human Rights. Oxford: Oxford University Press, 2008, p. 19.

46 GRIFFIN, On Human Rights. p. 16. 
E mais: a igualdade sempre pressupõe o exame de critérios de igualação (homem e mulher são iguais para fins tributários, mas não para licença maternidade); será que o critério da deficiência é o melhor para (des)igualar carentes e não carentes? É importante ver que o resultado da política legislativa é este: não são todos os carentes que gozarão de gratuidade, mas sim o deficientes carentes. Por que não as crianças carentes? Ou os idosos? Ou os estudantes? Valeria aqui o mesmo raciocínio?

Em suma, há no voto da Min. Cármen Lúcia, mais do que no do Min. Lewandowski, um germe de racionalidade a ser explorado na direção do sentido normativo da dignidade como status. No entanto, se o sentido da dignidade fica mais claro neste caso, ele não resolve a questão tout court.

\section{DIGNIDADE E PROVIMENTO DE CARGO PÚBLICO POR}

ESTRANGEIRO

Ao julgar por unanimidade, em 14.06.2011, o Ag. Reg. no RE 346.180/RS, a $2^{a}$ Turma do STF entendeu que, embora o "núcleo essencial" dos direitos atribuídos aos estrangeiros antes das Emendas Constitucionais 11/1996 e 19/1998 compreendesse as prerrogativas necessárias ao resguardo da dignidade humana, isso não abrangia o direito de ocupação de cargos públicos na estrutura administrativa brasileira.

O caso era este: um cidadão alemão integrava o quadro técnico da Universidade Federal de Santa Maria desde 1996 na condição de empregado público contratado pela CLT. Esse cidadão queria ver reconhecido o vínculo estatutário, para isso precisando afastar a incidência do óbice contido no $\S 6^{\circ}$ do art. 243 da Lei Federal 8.112/1990 (Estatuto dos Servidores Públicos Civis da União), o qual determina, em disposição transitória, que os estrangeiros com estabilidade no serviço público contratados pela lei anterior (Lei Federal 1.711/1952) passariam a integrar tabela em extinção, respeitados os direitos adquiridos, enquanto não adquirissem a nacionalidade brasileira. O cidadão alemão entendeu que essa norma era discriminatória dos estrangeiros. 
O Ministro Joaquim Barbosa, relator, em fundamentação sucinta, resolveu o caso em quatro parágrafos curtos, numa sequência argumentativa assim resumida: (1) os direitos e as garantias individuais, a igualdade inclusive, aplicam-se aos estrangeiros $\rightarrow$ (2) o núcleo essencial dos direitos dos estrangeiros abrangia a proteção à dignidade, mas isso não significava, até o advento das Emendas 11/1996 e 19/1998, que os estrangeiros poderiam ocupar cargos públicos, uma vez que o primitivo inc. I do art. 37 da CF contemplava apenas cidadãos brasileiros $\rightarrow$ (3) essa configuração normativa brasileira anterior configurava uma "tutela mais severa da soberania estatal", soberania essa que é "fundamento da República (art. 10 , I, CF) $\rightarrow$ (4) por tudo isso, o $\$ 6^{\circ}$ do art. 243 do Estatuto não fere a CF e permanece em vigor até que surja outra lei regulando o atual art. 37, I, CF. ${ }^{47}$

Em suma, a dignidade aparece en passant no voto, mas não tem papel maior. Fosse suprimida, não haveria qualquer prejuízo à conclusão. No entanto, para os propósitos deste ensaio, é importante frisar que o raciocínio levado a efeito pelo Ministro relator parece limitar a dignidade e conformá-la ao disposto na lei - é a lei que conforma e configura a dignidade, a qual "não abrange" o que não estiver estabelecido no Estatuto. A igualdade - que foi de certa forma equiparada à dignidade, ou, como querem os críticos da dignidade, a igualdade foi "ornamentada" pela dignidade - é a igualdade perante a e nos limites da lei.

Neste julgado é possível novamente notar a vinculação entre dignidade e igualdade. Com boa vontade talvez possamos ver que a ideia do status pode ajudar a compreender melhor qual o papel do termo "dignidade" no acórdão: é um papel "igualador", i.e., a dignidade pretenderia elevar os status do professor estrangeiro ao do brasileiro; noutras palavras, o estrangeiro queria a mesma "dignidade" do brasileiro. Isso, porém, foi negado pelo STF sobre o fundamento de que a igualdade (ou a dignidade) deve dar-se nos limites legais.

\section{DIGNIDADE E SERVIÇO DE TÁXI}

47 A redação atual do inc. I do art. 37 da CF, dada pela EC 19/1998, é esta: "os cargos, empregos e funções públicas são acessíveis aos brasileiros que preencham os requisitos estabelecidos em lei, assim como aos estrangeiros, na forma da lei". Para comparar, eis a redação original: "I - os cargos, empregos e funções públicas são acessíveis aos brasileiros que preencham os requisitos estabelecidos em lei" [grifei]. 
O último acórdão a analisar é o RE 359.444-3/RJ, j. em 24.03.2004, por maioria, pelo Pleno do STF, relator para o acórdão o Min. Marco Aurélio. O caso era bastante interessante: no Município do RJ, foi aprovada lei municipal transformando os motoristas auxiliares de táxi em permissionários autônomos. Essa lei foi julgada constitucional pelo Tribunal de Justiça do RJ, e o Prefeito do RJ recorreu ao STF, que manteve a decisão. ${ }^{48}$ Várias questões de direito administrativo e constitucional estavam envolvidas: se há necessidade de licitação em matéria de serviço de táxi, princípios da separação de poderes, isonomia, impessoalidade. Embora não fossem para o acórdão, essas questões são laterais aqui. O que importa é o voto do Min. Marco Aurélio, que abriu a divergência (ficou vencido o relator originário, Ministro Carlos Velloso) e, na sua argumentação, lançou mão da dignidade humana. Vejamos como e por quê.

A situação fática importa muito aqui. No Município do RJ (como talvez em todos os municípios de grande porte do Brasil) há um sério problema social na prestação de serviço de táxi, consistente na "exploração" dos motoristas por parte dos "donos da placa", da seguinte forma: o Município autoriza um determinado número de pessoas a explorar o serviço de táxi, mas essa pessoa "terceiriza", na maioria das vezes ilicitamente, a exploração do serviço para quem de fato dirige o táxi. Na prática, o autorizatário oficial, muitas vezes, não dirige o veículo; ele é o "dono da capelinha", como referiu o Min. Nelson Jobim no seu voto; quem dirige o táxi são chamados no acórdão de "motoristas auxiliares" ou "diaristas". O que a lei municipal fez foi, segundo o STF, buscar proteger esses auxiliares. E aqui entrou, pela voz de um só Ministro, o argumento da dignidade, o qual foi alocado na ementa do acórdão, como se fosse a razão de decidir da decisão. Explicito.

$O$ voto do Min. Marco Aurélio inicia e termina falando do aspecto social da lei. Na parte que interessa, o Ministro toca no ponto nevrálgico da questão: os motoristas auxiliares são em verdade explorados pelos "donos da capelinha". Dessa "exploração" o Min. Marco Aurélio entendeu estar violada a dignidade humana, que aparece no seu voto somente assim: "Atuou a Câmara, disciplinando a matéria, 48 Quem for conferir o acórdão do STF verá que há um equívoco no relatório do Min. Carlos Velloso, o qual informa --- eis o engano --- que o TJ RJ julgou inconstitucional a lei municipal do RJ, Lei 3.123/2000, quando o TJ RJ entendeu o contrário. A correção consta dos Embargos Declaratórios opostos ao acórdão e julgados à unanimidade pelo Pleno em 08.09.2004, rel. Min. Marco Aurélio. 
para finalizar algo que não poderia viger, em face de novos ares constitucionais e democráticos, no que dão ênfase maior, homenageiam a dignidade do homem". Nenhum outro ministro fez referência à dignidade. Ainda assim ela terminou posta na ementa, assim redigida:

TAXISTA - AUTONOMIA - DIARISTA - DIGNIDADE DA PESSOA HUMANA - TRANSFORMAÇÃO - LEI MUNICIPAL DO RIO DE JANEIRO $N^{\circ} 3.123 / 2000$ - CONSTITUCINOALIDADE. Sendo fundamento da República Federativa do Brasil a dignidade da pessoa humana, o exame da constitucionalidade de ato normativo faz-se considerada a impossibilidade de o Diploma Maior permitir a exploração do homem pelo homem. O credenciamento de profissionais do volante para atuar na praça implica ato do administrador que atende às exigências próprias à permissão e que objetiva, em verdadeiro saneamento social, o endosso de lei viabilizadora da transformação, balizada no tempo, de taxistas auxiliares permissionários. [grifei]

Essa ementa é rica para análise, desde a forma como foi produzida ao seu conteúdo. Ela em verdade não reflete fielmente a discussão havida no acórdão (de 49 laudas), que tratou de inúmeros temas de direito constitucional e administrativo, todos omitidos na ementa. Mas ela claramente vincula a dignidade ao imperativo moral kantiano que proíbe tratar homem como meio a atingir determinado fim. ${ }^{49}$ Todo o problema aqui é saber quando alguém é tratado como meio. Ocorre que estamos no campo do que Kant chamava autonomia (ou liberdade), e talvez não precisássemos nada além do conceito de autonomia para resolver a questão.

Vou colocar de outra forma o problema: seria possível "universalizar" o raciocínio do acórdão, i.e., estender a premissa a todos os casos de "exploração"? Noutra palavras, seguindo-se o raciocínio do acórdão, sempre que há "exploração do homem pelo homem", haveria afronta à dignidade, o que violaria um "fundamento da República Federativa do Brasil". A questão passa a ser esta: definir o que seja "exploração". Não arrisco resposta, mas quero ser bem compreendido: penso que a invocação da dignidade pelo STF (na verdade, por um único ministro) foi mais uma vez retórica e ornamental.

49 Eis o imperativo prático de Kant: "Age de tal maneira que uses a humanidade, tanto na tua pessoa como na pessoa de qualquer outro, sempre e simultaneamente como fim e nunca simplesmente como meio". KANT, Fundamentação da Metafísica dos Costumes. p. 69. 
Entretanto, é claro que a questão da "exploração" pode estar sim ligada à dignidade como status, e aqui a invocação da dignidade faz sentido, ao menos se aceitarmos a proposta de Waldron. Ao longo da história, a escravidão e a servidão foram reservadas aos que tinham status inferior, aos que não eram "dignos" de tratamento da nobreza. ${ }^{50}$ Se esse é o pressuposto teórico do Min. Marco Aurélio, não tenho qualquer objeção. O problema aqui, no entanto, parece ser de interpretação da força dos fatos: comparar os taxistas auxiliares a escravos parece exagero.

Em outras palavras, o silogismo do Min. Marco Aurélio este: Premissa Maior: explorar o homem é ferir sua dignidade $\rightarrow$ Premissa menor: o tratamento dados aos taxistas auxiliares é exploratório $\rightarrow$ Conclusão: o tratamento dados aos taxistas auxiliares fere a dignidade humana. Como comumente acontece com o raciocínio jurídico, o problema está na discordância quanto à formação das premissas. Neste caso, é certamente possível concordar com a premissa maior, mas não com a premissa menor.

\section{CONSIDERAÇÕES FINAIS}

Muitos defensores incondicionais da dignidade humana e quiçá alguns neoconstitucionalistas, com sua fé nos princípios, ${ }^{51}$ talvez vejam demasiado pessimismo nas linhas aqui descritas. O tema é sério, diriam eles, e o melhor que podemos fazer como juristas é tentar dar alguma racionalidade ao debate em torno da dignidade, que seria um "sobreprincípio" ou metanorma ou algo superior e fundante de todos os direitos; e citariam, com razão, o próprio Michael Rosen (mas contra Möllers), que propugna não o abandono da dignidade, mas sim o uso público do conceito de dignidade de forma menos retórica e mais consequente.

50 Ver notas 21 a 23 supra e texto correspondente.

51 O tema do neoconstitucionalismo é um mundo à parte. Tenho aqui em mente a caracterização feita por Humberto Ávila de que o neoconstitucionalismo se caracterizaria, dentre outras coisas, por preferir os princípios às regras. Ver ÁVILA, Humberto. "Neoconstitucionalismo": entre a "Ciência do Direito" e o "Direito da Ciência". Star Virgem, v. 21, p. 131150, 2010 (criticando a visão "princípios em vez de regras"). 
Concordo plenamente. O tema é seriíssimo, e que faríamos melhor se tentássemos construir um sentido à dignidade. Vou então ser mais direto, para não correr o risco de ser mal compreendido: o STF, ao menos nas decisões aqui comentadas, parece estar dando razão aos críticos da dignidade ao empregá-la no discurso público sem muito critério ou preocupação em melhor fundamentá-la, uma vez que não ofereceu ainda uma boa especificação de sentido do que entende por dignidade, se é que ofereceu alguma. Na maioria dos casos comentados, o papel da dignidade parece ser predominantemente retórico, ornamental. E no mais das vezes a dignidade é referida por somente um ministro, sendo difícil saber o que os demais pensam sobre o tema. O uso ornamental da dignidade, parece a mim, diminui a dignidade, não a eleva; isso equivale a degradar o status do conceito, não dignificá-lo.

Um leitor crítico pode fazer, contudo, ao menos uma contestação séria ao que está exposto anteriormente. Essa contestação poderia ser formada por um argumento de dois estágios: no primeiro, ela objetaria que a relação entre as duas partes deste ensaio é despropositada para efeitos de supostamente provar que o STF faz uso ornamental da dignidade. É que, diria o mesmo leitor, não se espera de juízes que façam filosofia ou teoria do direito em seus votos: juízes precisam resolver casos. Minha comparação implícita entre o filósofo Michael Rosen e, digamos, o Min. Marco Aurélio ou qualquer outro seria no mínimo descabida (para além de ser desigual), porque a atividade de ambos é e talvez mesmo deva ser essencialmente diversa. Assim, o ensaio aqui exposto só poderia mesmo ter o resultado que teve, e, no limite, acaba sendo uma empreitada fácil: conclusão parecida poderia provavelmente ser atingida tomando por base outros institutos ou conceitos jurídicos. Em suma, diria o leitor crítico, qualquer tema escolhido para análise em decisão do STF, se escrutinado analiticamente, levaria a conclusão de que o STF não usa critérios firmes ou coerentes.

No segundo estágio, o leitor crítico poderia elevar o tom do debate e aduzir que um empreendimento teórico mais consequente deveria não somente desconstruir as decisões do STF (essa é a tarefa fácil), mas sim tentar ajudar a construir um conceito de dignidade encontrando elementos comuns nas decisões judiciais que 
talvez possibilitassem encontrar o fundamento último tomado do conjunto das decisões judiciais, levando em conta não as palavras exatas utilizadas pelo STF, e sim o contexto no qual essas decisões foram tomadas, talvez sendo possível extrair delas um melhor e mais coerente sentido. É assim, concluiria o leitor crítico, que são construídos os institutos jurídicos nas culturas jurídicas desenvolvidas. ${ }^{52}$ Esse é, aliás, o papel mais fundamental da doutrina, concluiria o mesmo leitor. Preciso responder a essas objeções e vou tentar fazê-lo igualmente em dois estágios.

Primeiro, dizer que o trabalho de um juiz é diverso do de um filósofo ou teórico do direito e que seria despropositado compará-los só é correto se investigamos no que consiste essa diversidade e para que fins é feita a comparação. No que interessa aqui, qual seja, dar sentido ao conceito de dignidade humana, não me parece que haja diferença essencial no trabalho do teórico do direito ou filósofo e o do juiz, nem que seja indevida a comparação. O que fazem teóricos do direito e filósofos é tentar clarear os conceitos para que se operacionalizem na prática de forma minimante coerente; eles tentam, enfim, racionalizar os conceitos, explicálos, para que sejam operacionalizados praticamente, para que sirvam, no caso do direito, como parâmetros normativos de conduta, acaso sejam juridicizados.

Ocorre que os juízes fazem algo bastante parecido, valendo-se no mais das vezes da racionalização levada a efeito pelos teóricos do direito e dos filósofos políticos, com a diferença de que os juízes têm em regra menos preparo para essa específica empreitada (para além de não terem muitas vezes consciência dela). Mais importante, contudo, é que, quando os juízes dão sentido e concretizam um conceito como o de dignidade humana, o que resulta dessa interpretação é uma normatividade jurídica, i.e., uma norma coativamente imposta pelo Estado. E aqui sim há uma diferença brutal entre teóricos e filósofos versus juízes: o posição dos primeiros, por mais coerente ou correta ou brilhante, pode ter alguma influência, mas não tem força cogente direta, enquanto que a decisão judicial obriga e

52 Esses dois últimos parágrafos são construídos com base nas objeções críticas que em boa hora recebi de Ronaldo Porto Macedo Jr. quando da apresentação deste ensaio. Não faço aqui uma reprodução fiel da crítica, e provavelmente Ronaldo discorde da forma com que apresento aqui seu pensamento. Ele por certo reconstruiria suas objeções de forma mais sólida e coerente, talvez substancialmente diversa. Sei porém que na ocasião não fui capaz de refutá-las, nem tive tempo de sobre elas refletir. O que está no texto é uma tentativa de resposta a essas críticas, pelas quais agradeço. 
coage. Aliás, qual seria a finalidade da teoria do direito e da filosofia do direito se não pudéssemos usá-las como parâmetro de comparação para a argumentação utilizada pelos Tribunais? Por outro lado, qual a razão da empreitada teórica se não compartilharmos a visão de que é possível manejar o direito com um mínimo de racionalidade e oferecer ao operador jurídico um mínimo de previsibilidade na aplicação das normas jurídicas?

A resposta ao segundo estágio do argumento começa por acatá-lo na sua essência: sim, descontruir as decisões do STF e escancarar suas inconsistências é uma tarefa mais fácil do que construir um conceito de dignidade (e talvez de qualquer outro conceito ou instituto jurídico). No entanto, qualquer tarefa de construção deve começar por limpar o terreno no qual será erguida a obra. Também essa limpeza é importante. Analisar criticamente as decisões judiciais do STF em relação à dignidade e concluir que dessas decisões não se tem nada de muito consistente - ao contrário - não significa necessariamente propugnar pela extinção do uso do conceito (seja ele qual for).

Depois, devo dizer ainda que foi em resposta ao segundo estágio do argumento que empreendi, minimamente, o trabalho de sugerir que um germe talvez mais fértil para a solução do problema do emprego vazio, ornamental e perigoso da dignidade está na concepção de dignidade como status, entendendo-a como inter-relacionada à igualdade, um status a ser intentado e protegido pelo sistema jurídico. Não desenvolvi o argumento, é verdade, tarefa que mereceria maior elaboração. Mesmo assim, e ainda que a ideia de dignidade como status não seja a melhor e que o germe não dê frutos, não me parece que o trabalho de descontruir seja vão. Saber o que não se deve fazer é uma forma importante do saber o que fazer.

Em certos momentos deste ensaio falei de fachadas e arquitetura. Quero recuperar a metáfora agora. Um dos maiores administrativistas do Brasil, o Professor Almiro do Couto e Silva, o "último dos humanistas", como seus amigos costumam carinhosamente chamá-lo, sempre disse que a CF de 1988 é um documento de arte barroca, rico em ornamentos, repetições e abundância de reiterações, mas que essa característica foi pensada deliberadamente pelo 
legislador constituinte para deixar bem claro que precisávamos nos livrar, com as mesmas repetidas armas, dos desmandos reiterada e repetitivamente cometidos pelo Estado brasileiro e pela sociedade ao longo da nossa história; para o Professor Almiro, jurista sensível, culto e digno do nome como poucos, muito do que consta explícito na CF poderia ser dela facilmente extraído pela interpretação. ${ }^{53}$

É bem possível que seja assim. E talvez isso esteja se passando também com a ideia, ou o conceito, ou o princípio, ou a metanorma da dignidade humana. Mas eu gostaria de lembrar o outro lado da moeda, também espelhado no nosso passado: a história brasileira é a história da sobreposição de instituições, da repetição de ordens e comandos normativos, de todas as esferas, da jurídica em especial, no intuito de aplacar justamente os mesmos desmandos anteriormente referidos. Não parece, contudo, que estejamos colhendo frutos dessa sobreposição normativa e institucional.

Talvez sejam muito duras as palavras utilizadas por Michael Rosen na conclusão ao seu ensaio crítico, ao dizer que, ao melhor especificar o uso da "dignidade humana", evitaríamos que ela fosse usada como "cloaca na qual partes interessadas pretendem impor suas prescrições morais". Agrada-me, entretanto, o espírito da crítica de Rosen, e é ele que eu gostaria de enfatizar aqui: há alguma crueldade no uso da dignidade como fachada para esconder posições subjetivas e não racionalmente explicadas. Não creio que haja ganho na invocação ornamental da dignidade como "fundamento" de decidir casos jurídicos. Nem me parece que elevar a dignidade ao posto de "metanorma" possa reforçar-lhe a normatividade.

Meu desejo é que possamos, no futuro, repetir, sobre a Dignidade Humana, o mesmo que Marguerite Yourcenar fez o Imperador Adriano dizer das palavras Humanidade, Liberdade e Felicidade: que não desvalorizemos a dignidade pelo excesso de aplicações ridículas. Neste meu desejo há, claro, um exagero retórico de minha parte. A diferença é que o meu ornamento não tem força normativa. $\mathrm{E} o$ do STF tem. Dignificar a dignidade passa antes por não dar-lhe uso ornamental.

53 Ver o Prefácio de Almiro do Couto e Silva ao meu livro em GIACOMUZZI, A Moralidade Administrativa e a Boa-Fé da Administração Pública. p. 7. 


\section{REFERÊNCIAS}

ÁVILA, Humberto. "Neoconstitucionalismo": entre a "Ciência do Direito" e o "Direito da Ciência". Star Virgem, v. 21, p. 131-150, 2010.

ÁVILA, Humberto. Teoria dos Princípios. 15.ed. São Paulo: Malheiros, 2014.

BARROSO, Luís Roberto. Here, There, and Everywhere: Human Dignity in Contemporary Law and in the Transnational Discourse. Boston College International \& Comparative Law Review, v. 35, p. 331-393, 2012.

Dignidade da Pessoa Humana no Direito Constitucional Contemporâneo: A Construção de um Conceito Jurídico à Luz da Jurisprudência Mundial. Belo Horizonte: Fórum, 2013.

COUTO; SILVA. Almiro do. Prefácio. In: GIACOMUZZI, José Guilherme. A Moralidade Administrativa e a Boa-Fé da Administração Pública: o conteúdo dogmático da moralidade administrativa. 2. ed. São Paulo: Malheiros, 2013.

GIACOMUZZI, José Guilherme. A Moralidade Administrativa e a Boa-Fé da Administração Pública: o conteúdo dogmático da moralidade administrativa. 2.ed. São Paulo: Malheiros, 2013.

GRIFFIN, James. On Human Rights. Oxford: Oxford University Press, 2008.

GUGLIELMI, Gilles J.; KOUBI, Geneviève. Droit du service public. 2. ed. Paris: Montchrestien, 2007.

JUSTEN FILHO, Marçal. Curso de Direito Administrativo. 10. ed. São Paulo: Revista dos Tribunais, 2014.

. Direito Administrativo de Espetáculo. In: ARAGÃO, Alexandre Santos de; MARQUES NETO, Floriano de Azevedo (Coords.). Direito Administrativo e seus Novos Paradigmas. Belo Horizonte: Fórum, 2008, p. 65-85.

KANT. Fundamentação da Metafísica dos Costumes. Trad. Paulo Quintela. Lisboa: Edições 70, 1997 [1785].

A Metafísica dos Costumes. Tradução de José Lamego. Lisboa: Fundação Calouste Gulbenkian, 2005 [1797]. 
MCCRUDDEN, Christopher. In: Pursuit of Human Dignity: An Introduction to Current Debates. In: MCCRUDDEN, Christopher (Editor). Understanding Human Dignity. Oxford: Oxford U. Press, 2013, p. 1-58.

MÖLLERS, Christoph. The Triple Dilemma of Human Dignity. In: McCRUDDEN, Christopher (Editor). Understanding Human Dignity. Oxford: Oxford U. Press, 2013, p. 173-187.

ROSEN, Michael. Dignity: Its History and Meaning. Cambridge, MA: Harvard U. Press, 2012.

- Dignity: The Case Against. In: McCRUDDEN, Christopher (Editor). Understanding Human Dignity. Oxford: Oxford U. Press, 2013, p. 143-154.

WALDRON, Jeremy. How Law Protects Dignity? Cambridge Law Journal, v. 71, n. 1, p. 200222, March 2012. [doi:10.1017/S0008197312000256]

Is Dignity the Foundation of Human Rights? (January 3, 2013). NYU School of Law, Public Law Research Paper No. 12-73. Disponível em: SSRN: http://ssrn.com/ abstract=2196074 ou http://dx.doi.org/10.2139/ssrn.2196074

WHITMAN, James Q. Harsh Justice: Criminal Punishment and the Widening Divide between America and Europe. Oxford: Oxford University Press, 2003.

. "Human Dignity" in Europe and in the United States: The Social Foundations. Human Rights Law Journal, v. 25, p. 17-23, 2004.

. The Two Western Cultures of Privacy: Dignity Versus Liberty. Yale Law Journal, v. 113, p. 1151-1221, 2004.

YOURCENAR, Marguerite. Memórias de Adriano. Trad. Martha Calderaro. Rio de Janeiro: Nova Fronteira, 2005.

\section{ACÓRDÃOS DO STF ANALISADOS:}

RE 359.444-3/RJ, j. 24.03.2004, Pleno, rel. Min. Marco Aurélio Mello.

Ag. Reg. no RE 346.180/RS, j. 14.06.2011, 2a Turma, rel. Min. Joaquim Barbosa.

Ag. Reg. no AI 847.845/RJ, j. 11.12.2012, 1ª Turma, rel. Min. Luiz Fux. 
ADIn 2.649-6/DF, j. 08.05.2008, Pleno, rel. Min. Cármen Lúcia.

RE 227.480-7/RJ, j. 16.09.2008, $1^{\text {a }}$ Turma, rel. Min. Cármen Lúcia.

RE 190.264-7/RJ, j. 10.02.2000, Pleno, rel. Min. Nelson Jobim.

RE 229.450-8/RJ, j. 10.02.2000, Pleno, rel. Min. Maurício Corrêa.

ADIn 2.931-2/RJ, j. 24.02.2005, Pleno, rel. Min. Carlos Ayres Britto

MS 25.116/DF, j. 08.09.2010, Pleno, rel. Min. Carlos Ayres Britto

MS 28.720/DF, j. 20.03.2012, 2a Turma, rel. Min. Carlos Ayres Britto MS 24.268-0/MG, j. em 05.02.2004, Pleno, rel. Min. Gilmar Mendes.

Recebido em: jun/2014 Aprovado em: abr/2015 